\title{
Palaeoseismology of the Vilariça Segment of the Manteigas-Bragança Fault in northeastern Portugal
}

\author{
THOMAS ROCKWELL ${ }^{1}$, JOÃO FONSECA ${ }^{2}$, CHRIS MADDEN ${ }^{1}$, TIM DAWSON ${ }^{1,3}$, \\ LEWIS A. OWEN ${ }^{4}$, SUSANA VILANOVA ${ }^{5}$ \& PAULA FIGUEIREDO ${ }^{5,6}$ \\ ${ }^{1}$ Earth Consultants International, 1642 East 4th Street, Santa Ana, CA 92701, USA \\ ${ }^{2}$ Physics Department, IST, Av Rovisco Pais 1, 1049-001 Lisbon, Portugal \\ ${ }^{3}$ California Geological Survey, 345 Middlefield Road, MS520, Menlo Park, CA 94025, USA \\ ${ }^{4}$ Department of Geology, University of Cincinnati, PO Box 210013, Cincinnati, OH 45221, USA \\ ${ }^{5}$ ICIST, IST, Av Rovisco Pais 1, 1049-001 Lisbon, Portugal \\ ${ }^{6}$ LATTEX, Geology Department, University of Lisbon, Campo Grande, Lisbon, Portugal \\ *Corresponding author (e-mail: trockwell@geology.sdsu.edu)
}

\begin{abstract}
The Manteigas-Bragança fault is a major, 250-km-long, NNE-striking, sinistral strike-slip structure in northern Portugal. This fault has no historical seismicity for large earthquakes, although it may have generated moderate (M5+) earthquakes in 1751 and 1858. Evidence of continued left horizontal displacement is shown by the presence of Cenozoic pull-apart basins as well as late Quaternary stream deflections. To investigate its recent slip history, a number of trenches were excavated at three sites along the Vilariça segment, north and south of the Douro River. At one site at Vale Meão winery, the occurrence of at least two and probably three events in the past $14.5 \mathrm{ka}$ was determined, suggesting an average return period of about 5-7 ka. All three events appear to have occurred as a cluster in the interval between 14.5 and $11 \mathrm{ka}$, or shortly thereafter, suggesting a return period of less than 2 ka between events within the cluster. In the same area, a small offset rill suggests $2-2.5 \mathrm{~m}$ of slip in the most recent event and about $6.1 \mathrm{~m}$ after incision below a $c .16 \mathrm{ka}$ alluvial fill event along the Douro River. At another site along the Vilariça River alluvial plain, NE of the Vale Meão site, several trenches were excavated in late Pleistocene and Holocene alluvium, and exposed the fault displacing channel deposits dated to between 18 and $23 \mathrm{ka}$. In a succession of closely spaced parallel cuts and trenches, the channel riser was traced into and across the fault to resolve $c .6 .5 \mathrm{~m}$ of displacement after $18 \mathrm{ka}$ and $c .9 \mathrm{~m}$ of slip after $c .23 \mathrm{ka}$. These observations yield a slip rate of $0.3-0.5 \mathrm{~mm} / \mathrm{a}$, which is consistent with earlier estimates. Combining the information on timing at Vale Meão winery and displacement at Vilariça argues for earthquakes in the $\mathrm{M} 7+$ range, with coseismic displacements of 2-3 $\mathrm{m}$. This demonstrates that there are potential seismic sources in Portugal that are not associated with the 1755 Lisbon earthquake or the Tagus Valley, and, although rare, large events on the Vilariça fault could be quite destructive for the region. This work provides an analogue for the study of active faulting in intracontinental settings and supports the view that earthquakes within intracontinental settings tend to cluster in time. In addition, this study highlights the usefulness and application of multiple field, remote sensing and geochronological techniques for seismic hazard mitigation.
\end{abstract}

We investigated the late Quaternary (c. last 30000 years) rupture history of the Vilariça segment of the Manteigas-Bragança fault (called here Vilariça fault for simplicity) in the vicinity of the Douro River in northern Portugal (Fig. 1) as part of a seismic hazard investigation for a proposed dam across the Sabor River. This provided an opportunity to study the history and nature of intracontinental earthquakes in an area that is generally considered tectonically stable, and with low seismic hazard (see Vilanova \& Fonseca (2007) for an assessment of seismic hazard in Portugal).
For this study, we analysed stereo-paired aerial photography of about $25 \mathrm{~km}$ of the Vilariça fault to assess the overall expression of the fault, and to map landforms that are typically associated with active faults. We also used photography to select potential trench sites to date the timing of past surface ruptures. We then evaluated potential sites in the field for both access and to assess their likelihood for the presence of suitable stratigraphy and datability. Finally, we excavated six trenches at three sites to expose the fault and to study its late Quaternary history, and conducted additional 


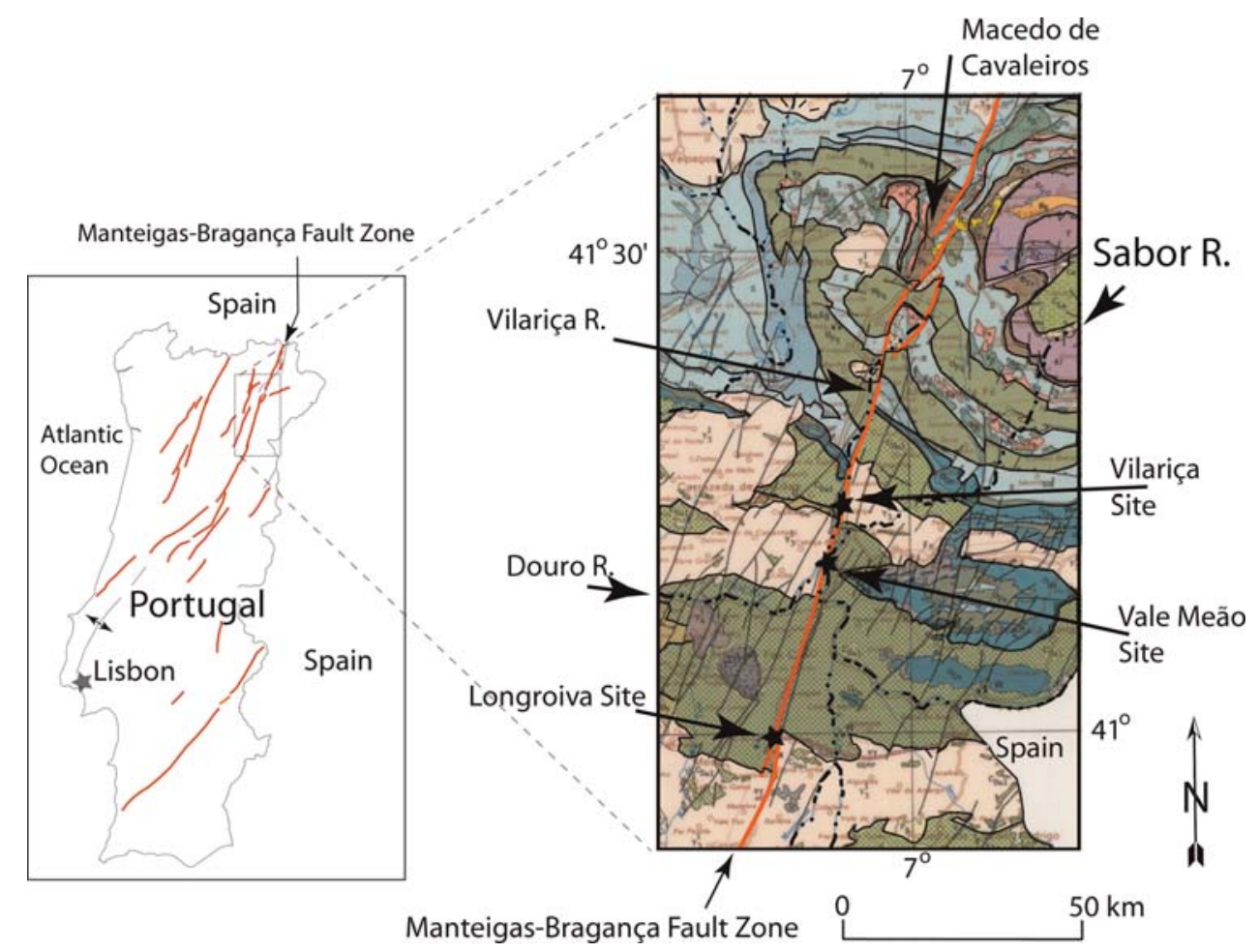

Fig. 1. Geological map of the study area in northeastern Portugal along the Manteigas-Bragança fault zone. The background map is scanned and modified from the 1992 version of the Carta Geológica de Portugal, produced by the Servicos Geológicos de Portugal. Note the left-lateral offset of the folded Palaeozoic strata along the ManteigasBragança and other parallel faults. Please refer to original map for description of units.

three-dimensional trenching at one of the sites to resolve displacement of a buried channel margin. This paper summarizes the results of these field studies, the first of this type along the Vilariça fault, and clearly demonstrates that there are large earthquake sources in northern Portugal that have been recurrently active in the late Quaternary. We begin with a brief background into the tectonic setting and current kinematic framework.

\section{Regional tectonic overview and current kinematic framework}

The tectonic setting of Portugal reflects a long history of deformations that extend back to the early Palaeozoic. Variscan basement rocks underlie most of western Iberia, with the Hesperian massif consisting of the most continuous fragment of Variscan basement in Europe (Ribeiro 1974, 1981; Ribeiro et al. 1979). The basement in the study area comprises primarily folded Precambrian to Devonian greywackes, schists and quartzites, intruded by granites (Cabral 1989).
The fold and thrust belt, within which this study is sited, formed in the Variscan Orogeny during the Carboniferous and into the Permian, with the early development of strike-slip faulting across the fold belt in late Variscan time. The Late Variscan NNE-SSW trending faults were considered as primary left-lateral faults by many workers (Ribeiro 1974, 1981; Arthaud \& Matte 1975; Ribeiro et al. 1979), although Marques et al. (2002) suggest that Variscan faulting may have been dextral, and later became sinistral during reactivation in the Alpine Orogeny. In Late Cretaceous to late Eocene, Iberia moved c. $120 \mathrm{~km}$ northward, producing the Pyrenean orogenic belt (Grimaud et al. 1982). The region experienced continued shortening in the Miocene (Ribeiro et al. 1990), with some activity persisting to the present on structures such as the Vilariça fault in northern Portugal (Cabral 1989) and other structures in Portugal (Cabral \& Ribeiro 1988).

Based on analysis of current seismicity, and structural indicators onshore and offshore of Portugal, Fonseca \& Long (1991) suggest that western Iberia is being extruded westward towards 
the Atlantic. This extrusion may have begun as early as the late Eocene but apparently was a major factor in the Alpine collision during the Miocene. Fonseca \& Long (1991) interpret the current activity on many faults as 'a subdued continuation of the upper Miocene evolution'. The extrusion model is significant because it: (1) allows for the reactivation of many basement strike-slip faults in Portugal, including the Vilariça fault; (2) explains the apparent activity of folds and thrusts offshore to the west; and (3) explains the current presence of seismic activity in and around Portugal.

The amount of Quaternary slip associated with these faults is yet to be defined, although at least the Vilariça fault has experienced moderate earthquakes in 1751 and 1858 (Vilanova \& Fonseca 2007). Furthermore, it is likely that fault reactivation has a long history. There is a total of $c .8 \mathrm{~km}$ of left slip on the Vilariça fault, as estimated from offset Palaeozoic folds measured from the geological map of Portugal (Fig. 1) (for the estimation of total lateral offset, we used sheets $11 \mathrm{C}$, Torre de Moncorvo, and 15A, Vila Nova de Foz Côa, published by the Serviços Geológicos de Portugal, both at a scale of 1:50000). However, this deformation has been accruing since the Palaeozoic, and if Marques et al. (2002) are correct, the sinistral displacement may have been superposed on some component of dextral slip. In any case, the fault has sufficient displacement to have developed a relatively straight, localized trace over a length scale of more than $100 \mathrm{~km}$.

Cabral $(1985,1989)$ was the first to delineate direct evidence of neotectonic activity along the Manteigas-Bragança fault, and he attributes the formation of the Vilariça basin as a pull-apart structure resulting from reactivation of the fault. Based on an inferred deflection of the Douro River, Cabral (1985) also attributes a slip rate of $0.2-0.5 \mathrm{~mm} / \mathrm{a}$ to this structure, which he states is "compatible with its regional geomorphic expression and historical seismicity'. Using this rate, only $0.4-1 \mathrm{~km}$ of slip would have accrued in the Quaternary. Thus, an assessment of the late Quaternary movement history of the Vilariça fault is important in quantifying the likely hazard posed to planned and existing dams in the Douro River region, and to the population in general. Towards that end, the focus of much of our work has been the establishment of the timing and size of past surface ruptures along the Vilariça segment of the fault, resolving its late Quaternary slip rate, and estimating the size and likelihood of future large earthquakes.

\section{Geomorphic analysis}

Black and white stereo aerial photographs (1:18 000 scale) purchased from the Instituto Geográfico de
Portugues in Lisbon were examined to identify active structures and map tectonic landforms, following the work of Cabral $(1985,1989)$ who mapped this same area at a scale of 1:25 000. The photographs were scanned at $800 \mathrm{dpi}(c$. half-metre pixels), and mosaics were constructed to compile the observations, as presented in Figures 2-4. We divided the study area into three subsections for ease of presentation. The northernmost section

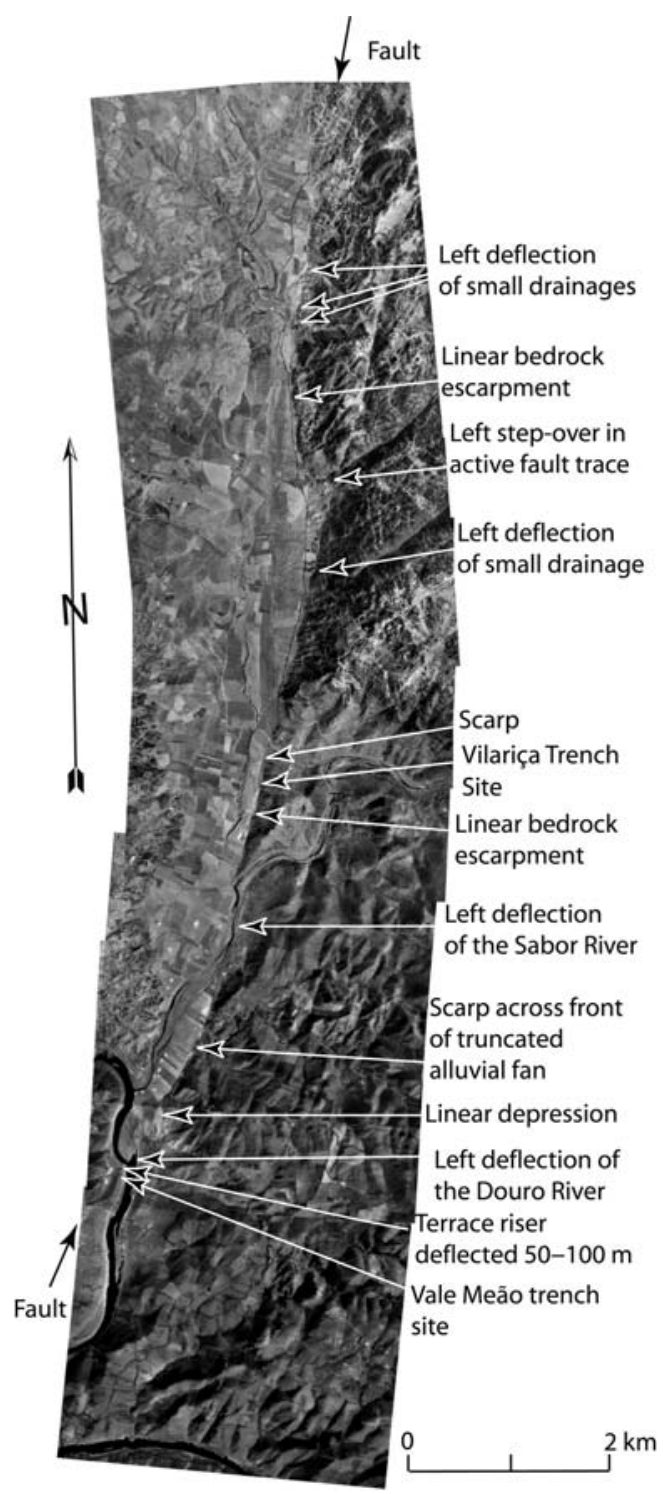

Fig. 2. Photomosaic of the fault zone in the northern area of detailed study along the Vilariça River southward to the Douro River, detailing the tectonic geomorphology in Vilariça basin. 


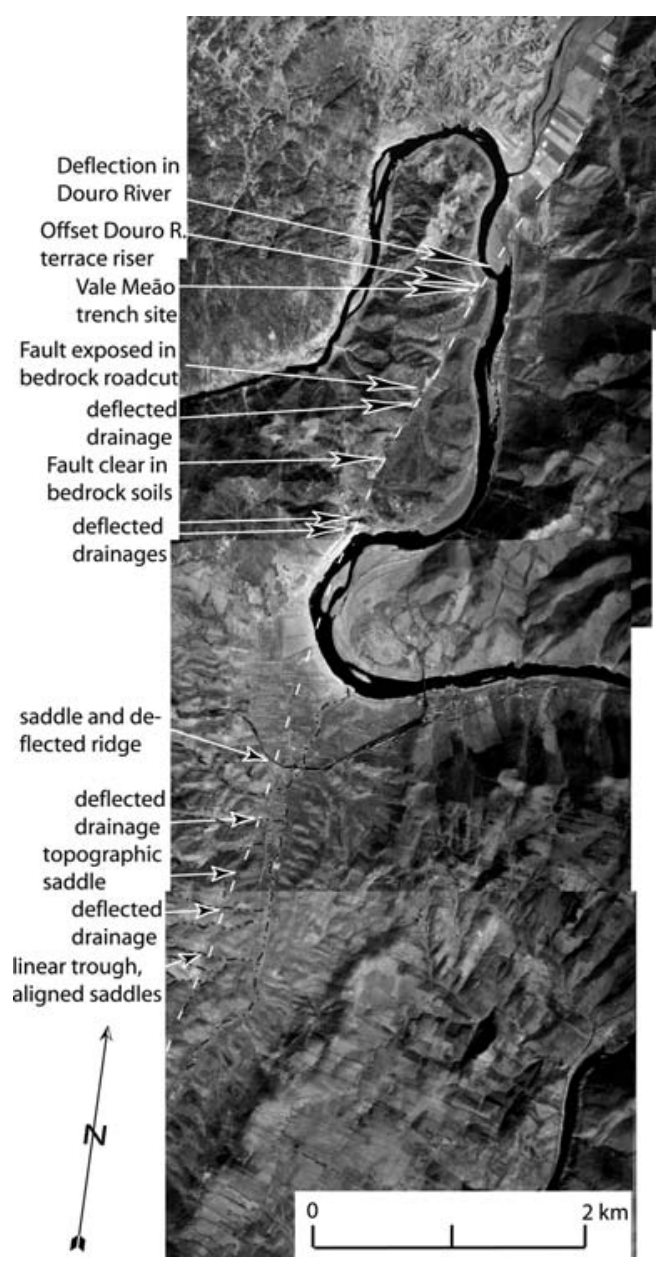

Fig. 3. Photomosaic of the fault zone in the central area, showing the Vilariça fault segment south of the Douro River.

includes the Vilariça basin southward to the northernmost bend of the Douro River (Fig. 2). The central section includes the northward bend of the Douro River and the Vale Meão winery (Quinta do Vale Meão) southward into the Ribeira do Vale da Vinha area (Fig. 3), whereas the south section extends down to Longroiva (Fig. 4). A short section in the upper Ribeira do Vale da Vinha/Vale do Escudeiro is not covered by any of the mosaics presented in Figures 2 to 4, but most of this area is undergoing erosion and features associated with recent activity are sparse.

\section{Northern section: Vilariça Basin}

The Vilariça fault is well expressed north of the Douro River in the area that Cabral (1985, 1989)

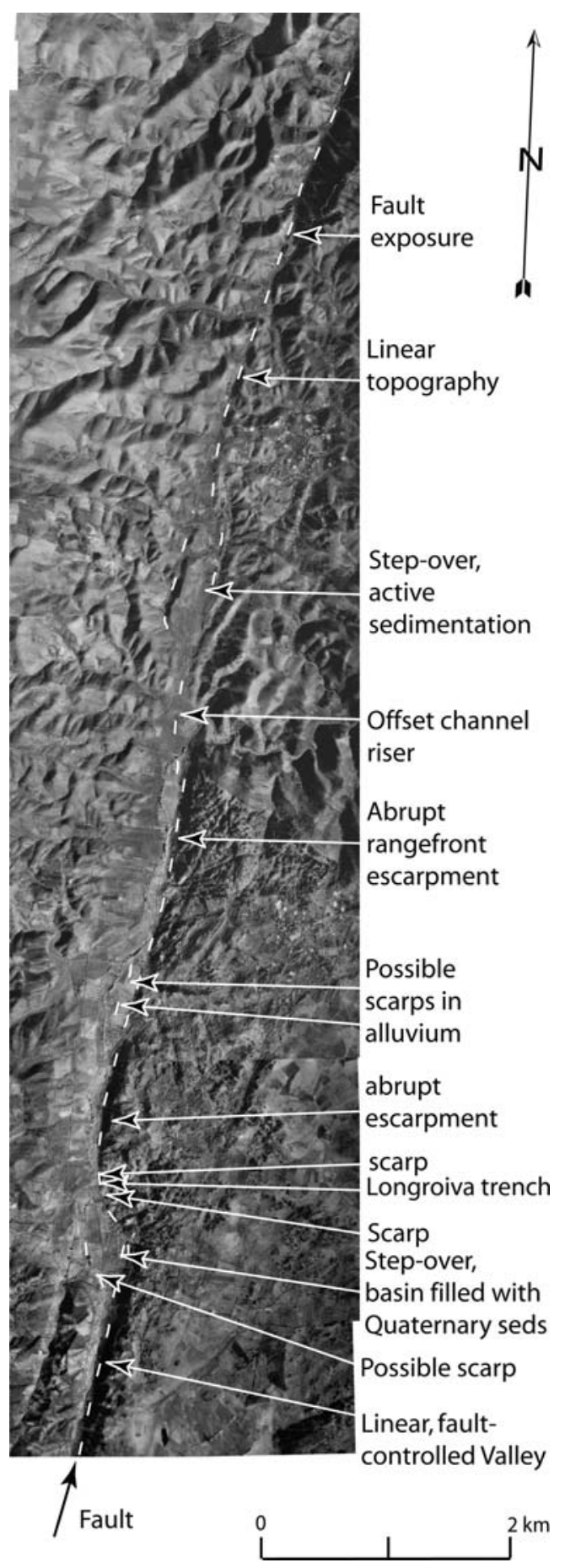

Fig. 4. Photomosaic of the fault zone in the southern area along the Vilariça fault segment, showing the tectonic geomorphology southward to the Longrovia area. 
called the Vilariça basin (Fig. 2). Much of the area along the fault has undergone Holocene deposition, with accumulations of young sediments against the bedrock escarpment that was produced by the fault. This has resulted in a very pronounced and linear escarpment that is clearly seen in Figure 2. The surface trace of the fault is mostly buried by late Holocene alluvium along much of the length of the Vilariça basin, both north and south of the basin's confluence with the Sabor River, as exposed in the Vilariça trenches discussed later in this paper. Nevertheless, the escarpment generally marks the location of the fault, although it is locally trimmed by the Vilariça and Sabor River margins.

Landforms specifically attributed to fault movement include offset or deflected drainages. These are well seen where they cross the fault in the northern Vilariça basin area (upper part of Fig. 2). Most of these channels are incised suggesting that erosion has dominated during the late Quaternary. There is a scarp that truncates an alluvial fan south of where the Sabor River enters the Vilariça basin. This scarp is related to either fault movement or erosion by the Sabor River. The Sabor River is also deflected to the left, but this is down the fluvial gradient towards the Douro River so the magnitude of the deflection is likely enhanced by this effect. Farther south, the course of the Douro River is strongly left-deflected at the fault. This deflection is pronounced and not likely the result of simple differential erosion. The rocks east of the fault are predominantly schist and should erode more rapidly than the granitoid rocks west of the fault. Nevertheless, the schist is shunted northward across the Douro River. We consider it likely that at least part of this deflection is related to slip on the Vilariça fault, especially considering that this is the largest (highest order) stream in this area and it would have been hard to overcome its erosive force if the fault had not been tectonically active. The deflection observed in Figure 2 is enhanced by ponding of the Douro River behind a hydroelectric dam across the river downstream from the fault. Hence, the deflection represents offset of the channel walls rather than the Holocene channel itself and probably represents slip that accrued after a major phase of incision during the Pleistocene. On the north margin of the Douro River, the deflection is also likely enhanced by deposition from the Sabor River, the confluence of which is very close to where the fault crosses the Douro.

\section{Central area south of the Douro River}

The area SW of the major northward bend in the Douro River, which includes the Vale Meão winery that hosts one of our trench sites, has several features that are likely the direct result of slip on the fault. The fault is well-expressed in the Vale Meão area, as shown in Figure 3. The southern terrace riser of the Douro River is left-deflected by c. $50-100 \mathrm{~m}$, which we interpret as largely the result of fault offset.

Farther south, the location of the fault is very clear in the aerial photography because the surface topography is undergoing erosion and the soils have developed very differently across either side of the fault. On the northwestern side, the granitic bedrock soil is much lighter in colour than the soil developed in the schist SE of the fault. The fault surface is well-exposed in at least one road-cut exposure, and striae on gouge of the active fault surface are nearly horizontal, indicating nearly pure horizontal motion, which is consistent with the surface morphology in this area.

There are several deflected or offset stream channels that incise the bedrock in the Vale Meão area. We interpret these as the result of long-term motion on the fault. The smallest of these deflections, located adjacent to the Douro River where the fault intersects the river on the SW edge of the Vale Meão winery, shows $c .2 .2 \mathrm{~m}$ of near-field left-lateral deflection and c. $6 \mathrm{~m}$ of far-field deflection on a small rill, as discussed later when we estimate slip per event. The next stream to the NE is deflected $c .50 \mathrm{~m}$ and the fault coincides precisely with the location of these deflections. There are also drainage basins within the Vale Meão winery that do not currently align with their principal channels and are likely offset.

To the SW of the Douro River, the location of the fault is inferred for several hundred metres, where it is buried beneath late Quaternary alluvium of Ribeira do Vale da Vinha. Farther south, the fault traverses an incised area with minor deflections of the principal channels (Fig. 3). The drainage courses are delineated on Figure 3 to illustrate that although deflections are present, they are relatively subtle. We interpret this to reflect the relatively low slip rate associated with the fault, because the overall geomorphology represents long-term incision.

\section{Southern section to Longroiva}

The fault makes several small, left (releasing) stepovers with intervening areas of late Quaternary sedimentation south of the drainage divide that separates Ribeira do Vale da Vinha from the Longroiva Valley. The Longroiva trench site is at the northern edge of the largest of these basins.

The fault is principally expressed as aligned linear escarpments and small scarps in bedrock and possibly alluvium (Fig. 4). An offset channel 
riser with several metres of deflection was mapped in the field, but this feature is not very apparent in the aerial photography (Fig. 4). In general, the surface expression of the fault along this southern section is subdued with less evidence for direct fault motion (channel offsets). This suggests that channel aggradation is younger in this area as compared to the other areas to the north.

\section{Summary}

The overall expression of the Vilariça fault in the area covered by Figures $2-4$ indicates that the principal sense of late Quaternary motion is left-lateral strike-slip, consistent with the sinistral displacement observed for the basement rocks. In areas undergoing erosion, channel and drainage basins are consistently deflected to the left. In general, the deeper incisions express greater amounts of deflection, and the smallest deflection of $c .2 .2 \mathrm{~m}$ is associated with a small rill. In areas where the fault steps to the left, young deposits bury the active trace of the fault, consistent with basin formation due to a releasing step-over. The general lack of scarps in Holocene alluvium suggests that either the sedimentation is generally younger than the most recent fault activity in most areas, that the evidence for young activity is generally not recognizable at the scale of the photos, or that recent agricultural activity has obliterated scarps and other youthful landforms associated with active faulting. In any case, the general expression of the geomorphology of the fault in the study area argues for an overall low late Quaternary slip rate, but one that has remained left-lateral.

\section{Trenching investigations}

Two of the principal tasks that we undertook in this study were to establish the timing of the most recent surface ruptures, and to assess the likely magnitude of these prehistorical earthquakes. Towards this end, we explored three sites in the subsurface to establish the recent slip history of the fault. At one of the sites, we conducted three-dimensional trenching to resolve displacement on a buried channel.

The success of a palaeoseismic site hinges on exposing good stratigraphy in an area of active sedimentation embedded with datable material, preferably detrital charcoal or peat. The good stratigraphy is required so as to recognize evidence for individual events. If the strata are too coarse, it is likely that some events will be unrecognized. Furthermore, coarse strata, such as channel gravel, are commonly associated with periods of erosion and may remove evidence for surface rupturing events. In an ideal site, there is sufficient sedimentation to separate evidence for discrete surface ruptures, but not so much to deeply bury the fault and make it difficult to study. Also, coarse strata tend to have much sparser concentrations of detrital charcoal and are harder to directly date with other methods, such as thermoluminescence or optically stimulated luminescence (OSL) dating. For all of these reasons, the best sites to date past earthquakes tend to be in areas of structural releasing step-overs, or in areas where sediment is ponded behind a scarp, as both environments tend towards moderate rates of sediment accumulation which are typically better at preserving palaeoseismic records.

For this study, we found no young sag ponds or other small-scale depressions that our experience has shown to be the best for palaeoseismic studies. Nevertheless, there did appear to be active sedimentation at all three of the sites we chose, although the stratigraphy at each site did pose its own unique challenges. The southernmost site at Longrovia, however, yielded low-resolution information as the main fault ruptures bedrock to the surface and is not overlain by an alluvial sequence. Hence, this site was abandoned to focus on the more promising Vale Meão winery and Vilariça sites. We discuss each of these two northern sites beginning with a brief description of the site and the rationale for choosing each trenching location. The work at Vale Meão is discussed first, as that site yielded the best data on timing of past events. The Vilariça site, in contrast, provided the best information on fault displacement.

\section{Vale Meão winery site}

The Vale Meão trench site was originally chosen to explore the possibility of determining a long-term slip rate. Figure 5 shows the detailed geomorphology in the Vale Meão area. In particular, it appears in the aerial photography that the Douro River channel wall, the riser to a major terrace, and potentially the terrace itself, are likely laterally offset by several tens of metres. The Douro River itself is likely deflected by up to a hundred metres. To explore the possibility of resolving a slip rate, we excavated a long trench (VM T-1) from the east side of the fault near the edge of the terrace westward across a drainage and up onto the terrace surface to the west. The intent was to cross the fault, resolve the locations of the fault and terrace edges on each side of the fault, and set up for trenches parallel to the fault to resolve slip on the terrace. Based on the location of the fault exposed in trench VM T-2, it is likely that we terminated the trench just east of the fault. Nevertheless, the trench exposed sediments that required rethinking of using this site to resolve a long-term slip. 


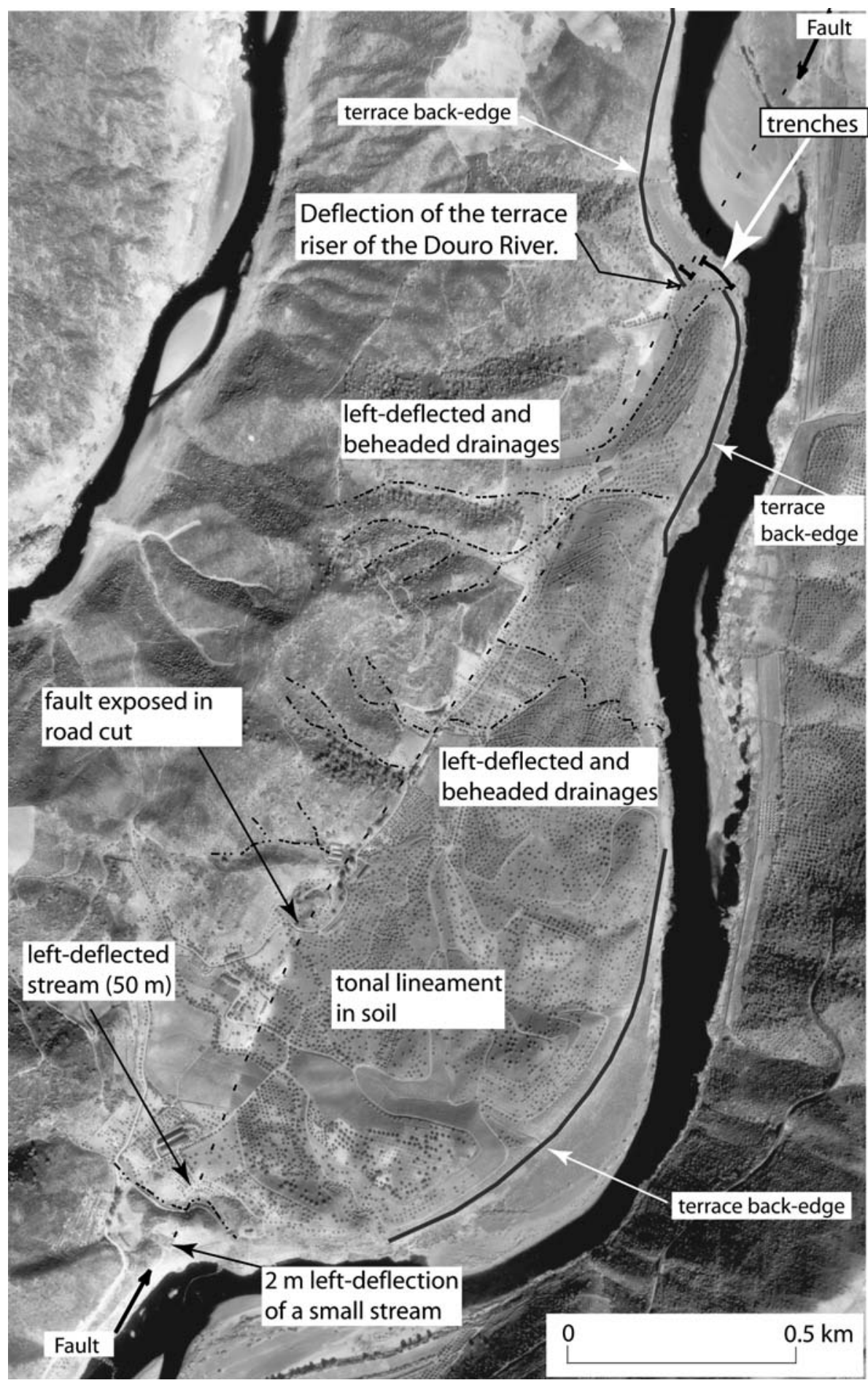

Fig. 5. Detail of the Vale Meão winery area showing the deflection of the Douro River and the trench site. The fault is clear in the geology and geomorphology. The interpreted location of the back-edge of the fill terrace exposed in trench T-1 at Vale Meão winery, dated at about $16 \mathrm{ka}$, is shown. 
In trench $\mathrm{T}-1$, the terrace comprised a massive fill event, rather than a strath (cut) surface, and was composed of very poorly bedded silt and sandy silt. On the stable terrace surface, the soil has a $1-2 \mathrm{~m}$ thick strong brown (7.5YR 4/5d) argillic horizon with common to many thin to moderately thick clay films. In southern California, which has a similar xeric climate and fluvial deposits with comparable parent material, this soil would be interpreted as having started to form in the late Pleistocene (Rockwell et al. 1985). In contrast, across the river to the NW in a road-cut, there is a strath terrace exposed with a much stronger soil (2.5-5YR 5/8 colour, plugged with clay) that is at a slightly higher elevation (by $c .10 \mathrm{~m}$ ) than the Vale Meão terrace. It is clear from trench T-1 and comparison of the soils that these are different terraces of very different ages, with the older and redder soil likely at least $100 \mathrm{ka}$ in age.

We collected two samples for OSL dating from the silty alluvial fill of this fill terrace, with resulting ages of $25.0 \pm 2.3 \mathrm{ka}$ and $16.0 \pm 1.1 \mathrm{ka}$. These dates do not overlap at $2 \sigma$ and suggest that at least the older date has a significant component of inheritance, especially as it is stratigraphically above the younger date (see discussion of OSL dating below). Nevertheless, the dates do support the soil observations that the alluvial fill event that comprises this terrace formed in the late Pleistocene. Considering that OSL dates are maximum ages because of the inheritance issue (Fuchs \& Lang 2008), the likely age of the fill event is $c .16 \mathrm{ka}$ or younger.

We interpret the geomorphic expression of the apparently offset terrace as simply reflecting deposition across the left-deflected riser to the Douro River. Thus, the fill does not date the deflection, but rather the fill drapes the deflection. In any case, sediments in trench VM T-1 show that the terrace was not the right type of terrace deposit to resolve a good, long-term slip rate.

Trench VM T-2, however, exposed the fault cutting late Quaternary deposits and yielded valuable information on the timing of the past two (and possibly three) surface ruptures. In the trench, Zedes Granite on the west was juxtaposed against phyllite of the Desejosa Formation on the east. A sequence of alluvial and colluvial deposits overlies the bedrock fault, and two strands of the fault extended upward to two different stratigraphic levels, indicating multiple events, as discussed in more detail below (Fig. 6).

Colluvial sediment dominated the stratigraphy in the trench. At least the upper part of the stratigraphically highest and youngest unit $\left(\mathrm{Col}_{1}\right)$ was found to bury a stone wall that was likely built in $c .1890$ during the early development of the winery. The wall was exposed in the eastward continuation of the trench, but this portion was back-filled for safety reasons. The modern A horizon soil caps this colluvial deposit.

Units $\mathrm{Col}_{2 \mathrm{~b}}$ and $\mathrm{Col}_{3 \mathrm{a}}$ are likely middle Holocene colluvial deposits, based on the radiocarbon ages of two detrital samples (VM-08 and VM-02, c. 4.8 and $4.65 \mathrm{ka}$, respectively; Table 1) collected from these units (Fig. 6). Unit $\mathrm{Col}_{3 \mathrm{a}}$ grades upward into the base of $\mathrm{Col}_{2}$, but they were differentiated in the field because $\mathrm{Col}_{2}$ apparently fills a fairly well-defined palaeogulley, whereas the contact between $\mathrm{Col}_{3 \mathrm{a}}$ and $\mathrm{Col}_{3 \mathrm{~b}}$ was very poorly defined and difficult to resolve. $\mathrm{Col}_{2}$ is capped by a buried A horizon that has a slightly darker appearance, indicative of slightly greater organic matter content, which in turn suggests some surface stability for a significant period of time.

$\mathrm{Col}_{3}$ represents a colluvial fill event that backfills a channel eroded into units $\mathrm{Col}_{4}$ to $\mathrm{Qa}_{6}$. The two radiocarbon age (c. $4.80 \mathrm{ka}$ and $4.65 \mathrm{ka}$; Table 1) indicate that $\mathrm{Col}_{3}$ and all overlying units are Holocene, and that $\mathrm{Col}_{2}$ and $\mathrm{Col}_{3 \mathrm{a}}$ were probably deposited in the middle Holocene and represent a period of colluvial aggradation.

Below the relatively massive middle to late Holocene colluvial deposits which tend to be organic-rich, units $\mathrm{Col}_{4}$ to $\mathrm{Qa}_{6}$ represent at least two phases of aggradation and incision, with some component of fluvial deposition, probably from the small drainage that runs through the site. Notably, these older units are essentially devoid of organic material, either as detrital charcoal or humus, and suggest accumulation under dryer conditions than are present today.

Unit $\mathrm{Qa}_{6}$ comprises stratified silty sand to gravelly sand and is likely a mix of colluvium and fluvial sediment. The sloping character of the overall unit, however, points more towards colluvial processes. $\mathrm{Qa}_{6}$ is cut out by an incision event, the channel of which is then backfilled by $\mathrm{Col}_{5 \mathrm{~b}}$, stratified alluvium of $\mathrm{Qa}_{5}$ and more colluvium of $\mathrm{Col}_{5 \mathrm{a}}$. $\mathrm{Col}_{4 \mathrm{~b}}$ is interpreted as a wedge or sheet of colluvium derived from the fault, as discussed below, and $\mathrm{Col}_{4 \mathrm{a}}$ is more colluvium with minor stratified sand and gravelly sand deposits embedded within it. The presence of water-laid sediments within the colluvium suggests that the system aggraded at least up to the level of the alluvial components.

We initially collected six OSL samples from units $\mathrm{Col}_{4}$ to $\mathrm{Qa}_{6}$, but the highest (youngest) and two lowest (oldest) samples disintegrated in transport to the laboratory in the USA. These three samples were re-collected along with an additional four samples, so ten OSL samples were altogether dated from this trench (Table 2).

OSL dating is used to determine the time elapsed since a sediment sample was exposed to daylight. This technique has been successfully applied to 


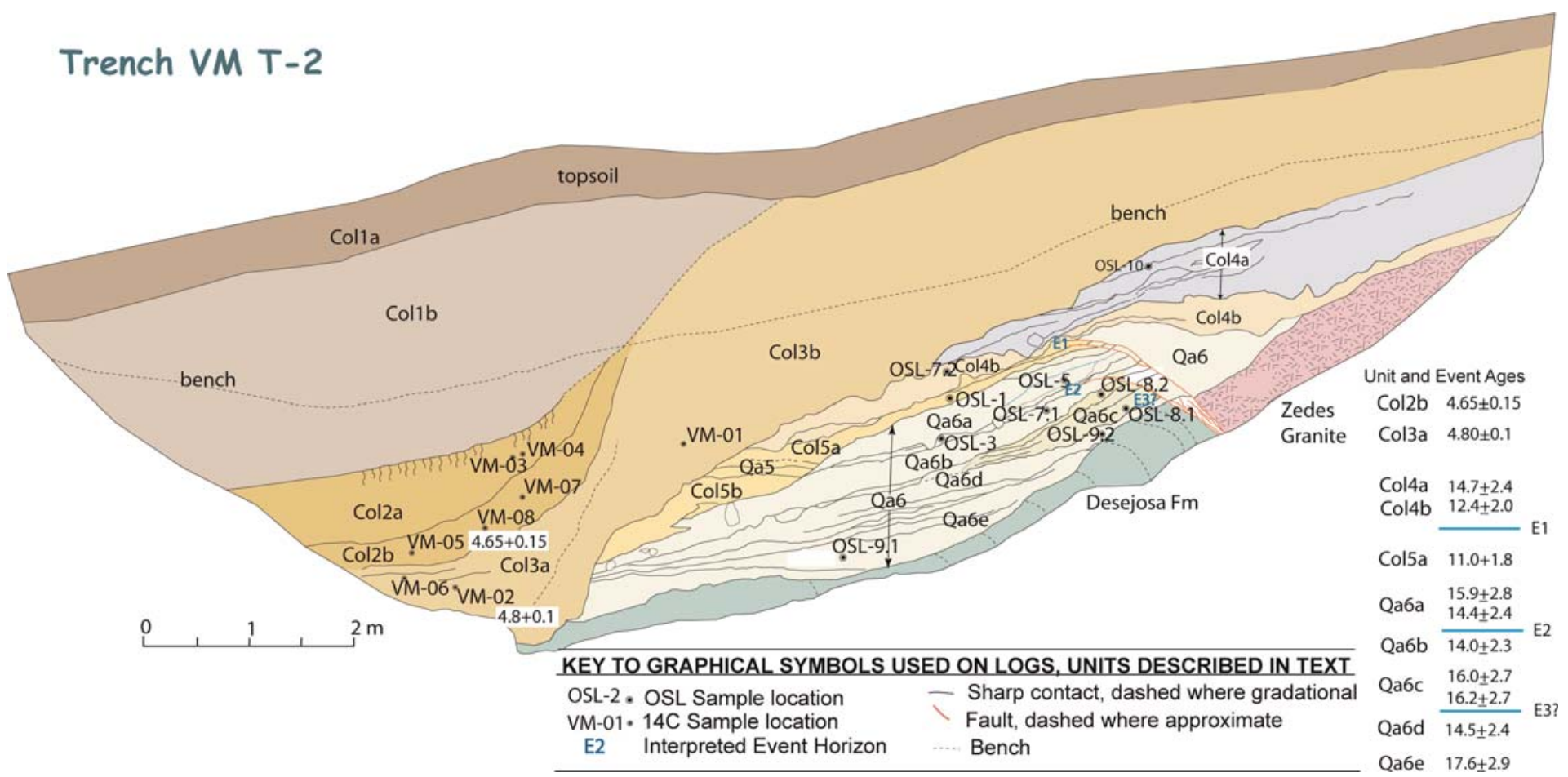

Fig. 6. Log of the VM T-2 trench at Vale Meão winery. Units and event interpretations are generally described in the text. 
Table 1. Radiocarbon ages for detrital charcoal samples recovered from sediments in the Vilariça (VR) and Vale Meão (VM) trenches

\begin{tabular}{lcccccccc}
\hline CAMS \# & Sample name & $\delta^{13} \mathrm{C}$ & Fraction modern & Error $( \pm)$ & $\mathrm{D}^{14} \mathrm{C}$ & Error $( \pm)$ & ${ }^{14} \mathrm{C}$ age & Cal. age (ka BP) \\
\hline 115427 & VR3-02 & -25 & 0.9705 & 0.0045 & -29.5 & 4.5 & $240 \pm 40$ & $0.05-0.5$ \\
115428 & VR3-04 & -25 & 0.9431 & 0.0040 & -56.9 & 4.0 & $470 \pm 35$ & $0.55 \pm 0.05$ \\
115429 & VM-02 & -25 & 0.5933 & 0.0028 & -406.7 & 2.8 & $4195 \pm 40$ & $4.8 \pm 0.1$ \\
115430 & VM-08 & -25 & 0.5988 & 0.0024 & -401.2 & 2.4 & $4120 \pm 35$ & $4.65 \pm 0.15$ \\
\hline
\end{tabular}

Sample names correlate to those on the respective trench logs.

dating deformed sediments for palaeoseismic studies in the western USA (e.g. Machette et al. 1992; Crone et al. 1997; Rockwell et al. 2000; Lee et al. 2001; Kent et al. 2005; Wesnousky et al. 2005) and elsewhere in the world (e.g. Owen et al. 1999; Washburn et al. 2001). The technique relies on the interaction of ionizing radiation with electrons within semi-conducting minerals resulting in the accumulation of charge in metastable location within minerals. Illuminating the minerals and detrapping the charge that combines at luminescence centres can determine the population of this charge. This results in the emission of photons (luminescence). Artificially dosing subsamples and comparing the luminescence emitted with the natural luminescence can determine the relationship between radiation flux and luminescence. The equivalent dose $\left(D_{E}\right)$ experienced by the grains during burial therefore can be determined. The other quantity needed to calculate the age is the ionizing radiation dose rate, which can be derived from direct measurements or measured concentrations of radioisotopes.

The uncertainty in the age is influenced by the systematic and random errors in the $D_{E}$ values and the possible temporal changes in the radiation flux. The quoted error is the deviation of the $D_{E}$ values on multiple subsamples and the error in measured ionizing radiation dose rate or the concentration of radioisotopes. Determining temporal changes in the dose rate that is a consequence of changes in water content and the growth and/or translocation of minerals within the sediment is not possible. The dose rate is therefore generally assumed to have remained constant over time.

For most deposits derived from a common source, the dose rate determined directly from those sediments commonly falls within a fairly narrow range as long as there are not secondary factors such as the accumulation of pedogenic carbonate or other authigenic deposits that have affected the post-deposition radiogenic content of the sample. The Vale Meão trench samples, however, produced dose rates that varied from $c .4$ to $7 \mathrm{mGy} / \mathrm{a}$ and yielded apparent ages that are stratigraphically reversed, with one of the youngest apparent ages at the bottom of the section (Table 2). Furthermore, there are no secondary minerals apparent in the sediments for which to attribute postdeposition changes in dose. We reanalysed the samples for dose and found surprisingly large variability from the same sample, as well as between samples that were collected very close to each other. These results indicated to us that there are surprisingly large, very local variations in dose rate. In that the final dose that a sample has been exposed to comes largely from the surrounding mass of sediments (out to $c .30 \mathrm{~cm}$ or so from the sample), we decided to take the mean of all of the dose results from the Vale Meão OSL samples and apply that dose rate to all of the samples to calculate their ages. We also applied the standard deviation in the mean of the dose rate samples as an added uncertainty in the age calculations. In so doing, the resulting dates are mostly in stratigraphic order, with only a couple of very minor age inversions that are likely the result of inheritance. We present all of the dose data, as well as the calculated ages using both the direct and average dose rates, in Table 2 . For the balance of this discussion, we use only the ages calculated from the average dose rate, as those ages appear to provide good stratigraphic coherence. For samples that are age-reversed, we assume that part of this reversal is due to the inheritance effect that is common in OSL dates.

The OSL results indicate that all of the $\mathrm{Col}_{4}$ to $\mathrm{Qa}_{6}$ units were deposited in the latest Pleistocene between $c .11$ and $18 \mathrm{ka}$, with the lower part of $\mathrm{Qa}_{6}$ dating to about the same age as the fine-grained fill exposed in trench VM-1. This observation suggests that the alluvial and colluvial fill exposed in trench VM-2 may have been forced by the same factors (climate change, tectonics, allocyclic processes) causing aggradation of the main Douro River channel. The absence of organic material (humus, charcoal) in the latest Pleistocene section, and its abundance in the late Holocene section, is consistent with development under dryer climate conditions, as have been suggested for this region during the latter part of the last glacial by Sobrino et al. (2007). 
Table 2. Summary of OSL dating results from quartz extracted from sediment matrices

\begin{tabular}{|c|c|c|c|c|c|c|c|c|c|c|c|c|c|}
\hline Sample number & Unit & $\begin{array}{l}\text { Location } \\
\left({ }^{\circ} \mathrm{N} /{ }^{\circ} \mathrm{W}\right)\end{array}$ & $\begin{array}{l}\text { Altitude } \\
\text { (m a.s.1) }\end{array}$ & $\begin{array}{l}\text { Depth } \\
(\mathrm{cm})\end{array}$ & $\begin{array}{c}\mathrm{U}^{a} \\
(\mathrm{ppm})\end{array}$ & $\begin{array}{c}\mathrm{Th}^{a} \\
(\mathrm{ppm})\end{array}$ & $\begin{array}{l}\mathrm{K}^{a} \\
(\%)\end{array}$ & $\begin{array}{l}\mathrm{Rb}^{a} \\
(\mathrm{ppm})\end{array}$ & $\begin{array}{c}\text { Cosmic dose } \\
\operatorname{rate}^{b, c}(\mathrm{mGy} / \mathrm{a})\end{array}$ & $\begin{array}{c}\text { Total dose } \\
\text { rate }^{b, d}(\mathrm{mGy} / \mathrm{a})\end{array}$ & $\mathrm{N}^{e}$ & $\begin{array}{c}\text { Mean } \mathrm{D}_{\mathrm{E}}^{f} \\
(\mathrm{~Gy})\end{array}$ & $\operatorname{Age}^{g}(\mathrm{ka})$ \\
\hline VM-10 & Col4a & $41.168 / 7.113$ & 115 & 180 & $\begin{array}{l}5.2 \\
4.5\end{array}$ & $\begin{array}{l}11.8 \\
10.4\end{array}$ & $\begin{array}{l}2.2 \\
2.3\end{array}$ & $\begin{array}{l}214 \\
215\end{array}$ & 0.17 & $\begin{array}{l}3.99 \pm 0.23 \\
3.81 \pm 0.23 \\
\mathbf{3 . 9 0} \pm \mathbf{0 . 1 6}\end{array}$ & $24(30)$ & $72.0 \pm 8.5$ & $\begin{array}{l}18.5 \pm 0.9 \\
14.7 \pm 2.4\end{array}$ \\
\hline VM-7.2 & Col4b & $41.168 / 7.113$ & 115 & 248 & $\begin{array}{l}5.7 \\
4.6\end{array}$ & $\begin{array}{l}9.3 \\
4.6\end{array}$ & $\begin{array}{l}3.4 \\
2.6\end{array}$ & $\begin{array}{l}420 \\
348\end{array}$ & 0.16 & $\begin{array}{l}5.01 \pm 0.32 \\
3.89 \pm 0.24 \\
\mathbf{4 . 2 9} \pm \mathbf{0 . 1 9}\end{array}$ & $17(30)$ & $60.7 \pm 8.0$ & $\begin{array}{l}14.2 \pm 0.8 \\
12.4 \pm 2.0\end{array}$ \\
\hline VMT1-OSL1 $^{h}$ & Col5a & $41.168 / 7.113$ & 115 & 290 & 7.1 & 10.9 & 1.6 & 123 & 0.15 & $4.04 \pm 0.24$ & $20(28)$ & $53.9 \pm 10.1$ & $\begin{array}{l}13.8 \pm 1.2 \\
11.0 \pm 1.8\end{array}$ \\
\hline VMT1-OSL5 ${ }^{h}$ & Qa6a & $41.168 / 7.113$ & 115 & 300 & 6.3 & 7.5 & 3.0 & 328 & 0.15 & $4.89 \pm 0.31$ & $11(28)$ & $77.9 \pm 32.2$ & $\begin{array}{l}11.0 \pm 1.0 \\
15.9 \pm 2.4 \\
15.9 \pm 3.2\end{array}$ \\
\hline VMT1-OSL $3^{h}$ & Qa6a & $41.168 / 7.113$ & 115 & 320 & 6.0 & 8.9 & 2.5 & 235 & 0.14 & $4.40 \pm 0.27$ & $20(28)$ & $70.6 \pm 13.1$ & $\begin{array}{l}16.1 \pm 1.4 \\
14.4 \pm 2.4\end{array}$ \\
\hline VM-7.1 & Qa6b & $41.168 / 7.113$ & 115 & 305 & $\begin{array}{r}11.4 \\
8.0\end{array}$ & $\begin{array}{l}8.8 \\
6.9\end{array}$ & $\begin{array}{l}2.7 \\
2.5\end{array}$ & $\begin{array}{l}272 \\
243\end{array}$ & 0.15 & $\begin{array}{l}5.55 \pm 0.33 \\
4.50 \pm 0.27 \\
\mathbf{4 . 9 2} \pm \mathbf{0 . 2 1}\end{array}$ & $16(24)$ & $68.8 \pm 8.3$ & $\begin{array}{l}14.0 \pm 0.7 \\
14.0 \pm 2.3\end{array}$ \\
\hline VM-8.2 & Qa6c & $41.168 / 7.113$ & 115 & 300 & $\begin{array}{l}9.5 \\
9.0\end{array}$ & $\begin{array}{l}11.4 \\
10.4\end{array}$ & $\begin{array}{l}3.4 \\
2.6\end{array}$ & $\begin{array}{l}363 \\
312\end{array}$ & 0.15 & $\begin{array}{l}5.90 \pm 0.36 \\
5.07 \pm 0.30 \\
\mathbf{5 . 4 1} \pm \mathbf{0 . 2 3}\end{array}$ & $21(24)$ & $78.8 \pm 14.0$ & $\begin{array}{l}14.6 \pm 0.8 \\
16.0 \pm 2.7\end{array}$ \\
\hline VM-8.1 & Qa6c & $41.168 / 7.113$ & 115 & 317 & $\begin{array}{l}7.4 \\
7.0\end{array}$ & $\begin{array}{r}13.0 \\
7.0\end{array}$ & $\begin{array}{l}3.9 \\
3.2\end{array}$ & $\begin{array}{l}420 \\
369\end{array}$ & 0.15 & $\begin{array}{l}6.01 \pm 0.37 \\
5.23 \pm 0.32 \\
\mathbf{5 . 5 6} \pm \mathbf{0 . 2 4}\end{array}$ & $28(30)$ & $79.6 \pm 15.3$ & $\begin{array}{l}14.3 \pm 0.8 \\
16.2 \pm 2.7\end{array}$ \\
\hline VM-9.1 & Qa6e & $41.168 / 7.113$ & 115 & 395 & $\begin{array}{l}8.2 \\
9.4\end{array}$ & $\begin{array}{l}13.5 \\
11.3\end{array}$ & $\begin{array}{l}3.2 \\
2.3\end{array}$ & $\begin{array}{l}268 \\
210\end{array}$ & 0.13 & $\begin{array}{l}5.56 \pm 0.33 \\
4.93 \pm 0.29 \\
\mathbf{5 . 2 0} \pm \mathbf{0 . 2 2}\end{array}$ & $27(30)$ & $86.4 \pm 16.5$ & $\begin{array}{l}16.6 \pm 0.9 \\
17.6 \pm 2.9\end{array}$ \\
\hline VM-9.2 & Qa6e & $41.168 / 7.113$ & 115 & 340 & $\begin{array}{l}14.3 \\
12.2\end{array}$ & $\begin{array}{l}14.8 \\
13.1\end{array}$ & $\begin{array}{l}3.1 \\
2.8\end{array}$ & $\begin{array}{l}277 \\
269\end{array}$ & 0.14 & $\begin{array}{l}6.95 \pm 0.41 \\
6.13 \pm 0.36 \\
\mathbf{6 . 4 9} \pm \mathbf{0 . 2 7}\end{array}$ & $24(30)$ & $71.2 \pm 9.7$ & $\begin{array}{l}11.0 \pm 0.5 \\
14.5 \pm 2.4\end{array}$ \\
\hline VR3-2 ${ }^{h}$ & Qa2 & $41.215 / 7.095$ & 120 & 275 & 6.4 & 17.2 & 2.8 & 194 & 0.15 & $5.38 \pm 0.32$ & $19(28)$ & $102.2 \pm 28.3$ & $18.2 \pm 1.6$ \\
\hline VR 3-1 & Qa2 & $41.212 / 7.094$ & 120 & 315 & $\begin{array}{l}5.2 \\
4.9\end{array}$ & $\begin{array}{l}15.5 \\
14.8\end{array}$ & $\begin{array}{l}2.6 \\
2.2\end{array}$ & $\begin{array}{l}195 \\
191\end{array}$ & 0.15 & $\begin{array}{l}4.54 \pm 0.27 \\
4.05 \pm 0.23 \\
\mathbf{4 . 2 6} \pm \mathbf{0 . 1 8}\end{array}$ & 24 & $>108^{j}$ & $>25$ \\
\hline VM PLEISTOCENE & & $41.168 / 7.113$ & 112 & 250 & $\begin{array}{l}5.2 \\
5.3\end{array}$ & $\begin{array}{l}14.6 \\
14.8\end{array}$ & $\begin{array}{l}2.1 \\
1.9\end{array}$ & $\begin{array}{l}127 \\
124\end{array}$ & 0.16 & $\begin{array}{l}4.05 \pm 0.23 \\
3.90 \pm 0.22 \\
\mathbf{3 . 9 7} \pm \mathbf{0 . 1 6}\end{array}$ & $18(24)$ & $64.9 \pm 10.3$ & $16.3 \pm 0.9$ \\
\hline
\end{tabular}


Table 2. Continued

\begin{tabular}{|c|c|c|c|c|c|c|c|c|c|c|c|c|c|}
\hline Sample number & Unit & $\begin{array}{l}\text { Location } \\
\left({ }^{\circ} \mathrm{N} /{ }^{\circ} \mathrm{W}\right)\end{array}$ & $\begin{array}{l}\text { Altitude } \\
\text { (m a.s.l) }\end{array}$ & $\begin{array}{l}\text { Depth } \\
(\mathrm{cm})\end{array}$ & $\begin{array}{c}\mathrm{U}^{a} \\
(\mathrm{ppm})\end{array}$ & $\begin{array}{l}\mathrm{Th}^{a} \\
(\mathrm{ppm})\end{array}$ & $\begin{array}{l}\mathrm{K}^{a} \\
(\%)\end{array}$ & $\begin{array}{c}\mathrm{Rb}^{a} \\
(\mathrm{ppm})\end{array}$ & $\begin{array}{c}\text { Cosmic dose } \\
\operatorname{rate}^{b, c}(\mathrm{mGy} / \mathrm{a})\end{array}$ & $\begin{array}{c}\text { Total dose } \\
\text { rate }^{b, d}(\mathrm{mGy} / \mathrm{a})\end{array}$ & $\mathrm{N}^{e}$ & $\begin{array}{l}\text { Mean } D_{E}^{f} \\
(G y)\end{array}$ & $\operatorname{Age}^{g}(\mathrm{ka})$ \\
\hline VM-UPPERP $^{h}$ & & $41.168 / 7.113$ & 115 & 150 & 5.6 & 18.0 & 2.1 & 123 & 0.18 & $4.57+0.26$ & $20(28)$ & 134.8 & $25.0+2.3$ \\
\hline VROSL3/VR3V & & $41.212 / 7.094$ & 120 & 290 & $\begin{array}{l}3.4 \\
4.0\end{array}$ & $\begin{array}{l}6.5 \\
8.1\end{array}$ & $\begin{array}{l}1.7 \\
1.9\end{array}$ & $\begin{array}{l}247 \\
198\end{array}$ & 0.15 & $\begin{array}{l}2.83 \pm 0.17 \\
3.21 \pm 0.19 \\
\mathbf{3 . 0 0}+\mathbf{0 . 1 3}\end{array}$ & $12(24)$ & $91.3 \pm 18.7$ & $30.4 \pm 2.4$ \\
\hline VR2 OSL4/VR 2-4 & Qt & $41.212 / 7.094$ & 120 & 290 & $\begin{array}{l}3.9 \\
3.2\end{array}$ & $\begin{array}{l}9.9 \\
7.0\end{array}$ & $\begin{array}{l}2.6 \\
2.4\end{array}$ & $\begin{array}{l}178 \\
156\end{array}$ & 0.15 & $\begin{array}{l}3.86 \pm 0.24 \\
3.32 \pm 0.12 \\
\mathbf{3 . 4 3} \pm \mathbf{0 . 1 1}\end{array}$ & $8(12)$ & $132.4 \pm 8.4$ & $38.6 \pm 2.7$ \\
\hline
\end{tabular}

${ }^{a}$ Elemental concentrations from NAA of whole sediment measured at Becquerel Laboratories, Lucas Heights, NSW, Australia, for samples shown in normal text, and at USGS Nuclear Facility in Denver for samples shown in italics. Uncertainty taken as $+10 \%$. Elemental concentrations shown in italics are duplicate samples.

${ }^{b}$ Estimated fractional water content from whole sediment (Aitken 1998). Uncertainty taken as $10 \pm 5 \%$.
E

${ }^{b}$ Estimated fractional water content from whole sediment (Aitken 1998). Uncertainty taken as $10 \pm 5 \%$.
${ }^{c}$ Estimated contribution to dose rate from cosmic rays calculated according to Prescott \& Hutton (1994). Uncertainty taken as $+10 \%$.

${ }^{c}$ Estimated contribution to dose rate from cosmic rays calculated according to Prescott \& Hutton (1994). Uncertainty taken as $\pm 10 \%$.
${ }^{d}$ Total dose rate from beta, gamma and cosmic components. Beta attenuation factors for U, Th and K compositions incorporating grain size factors from Mejdahl (1979). Beta attenuation factor for Rb arbitrarily taken as 0.75 (cf. Adamiec \& Aitken 1998). Factors utilized to convert elemental concentrations to beta and gamma dose rates from Adamiec \& Aitken (1998) and beta and gamma components attenuated for moisture content. Dose rates shown in italics are based on the elemental concentrations for the duplicate samples, while those in bold are the weighted mean doses based on original an duplication dose rates.

${ }^{e}$ Number of replicated $\mathrm{D}_{\mathrm{E}}$ estimates used to calculate mean $\mathrm{D}_{\mathrm{E}}$. The number in parentheses is the total number of aliquots measured. These are based on recuperation error of $<10 \%$.

${ }^{f}$ Mean equivalent dose $\left(\mathrm{D}_{\mathrm{E}}\right)$ determined from replicated single-aliquot regenerative-dose (SAR; Murray \& Wintle 2000) runs. Errors are 1 -sigma incorporating error from beta source estimated at about $\pm 5 \%$.

${ }^{g}$ Errors incorporate dose rates errors and 1-sigma standard errors (i.e. $\sigma_{\mathrm{n}-1} / \mathrm{n}^{\frac{1}{2}}$ ) for $\mathrm{D}_{\mathrm{E}}$ using the weighted mean of dose rates determined at Becquerel Laboratories and the USGS Nulcear facility in Denver.

Values shown in italics are calculated using a dose rate of $4.91 \pm 0.79 \mathrm{~Gy} /$ ka determined from the mean of the fault trench samples with the error being the standard deviation of the dose rates.

${ }^{h}$ Samples measured on a Daybreak OSL reader. All other samples were measured on a Riso OSL reader. 


\section{Interpretation and timing of faulting events}

We see clear evidence of two surface ruptures, and probably a third surface rupture, exposed in trench VM T-2. The youngest rupture breaks up through unit $\mathrm{Col}_{5 \mathrm{a}}$ and is overlain by unit $\mathrm{Col}_{4 \mathrm{~b}}$. $\mathrm{Col}_{4 \mathrm{~b}}$ is interpreted as a colluvial deposit that was shed directly off of the fault and resulted from this event, designated as E1 in Figure 6. Units $\mathrm{Col}_{4 \mathrm{a}}$ and $\mathrm{Col}_{3}$ are unbroken and must post-date the most recent surface rupture. A sample for OSL dating from the highest displaced unit $\left(\mathrm{Col}_{5 \mathrm{a}}\right)$ yielded an age of $11.0 \pm 1.8 \mathrm{ka}$. The OSL age from $\mathrm{Col}_{4 \mathrm{~b}}$ that caps the event had a similar age of $12.4 \pm 2.0 \mathrm{ka}$, which overlaps within uncertainty with the sample from $\mathrm{Col}_{5 \mathrm{a}}$. The sample from the stratigraphically higher $\mathrm{Col}_{4 \mathrm{a}}$ had a slightly discordant age of $14.7 \pm 2.4 \mathrm{ka}$ and apparently has some inherited signal, although even this date barely overlaps with the youngest of the three OSL ages. At face value, these data suggest that the most recent event (E1) occurred in the latest Pleistocene soon after $11 \mathrm{ka}$.

The most conservative assessment of the timing of E1 is provided by assuming that the OSL dates are maximum ages and by using the two radiocarbon samples that we dated from unfaulted units $\mathrm{Col}_{3 \mathrm{a}}$ and $\mathrm{Col}_{2 \mathrm{~b}}$, which yielded calibrated ages of c. 4.65-4.80 ka. Using these data, the timing of the most recent event is constrained to have ruptured the Vilarica fault segment sometime between 4.8 and $11 \mathrm{ka}$. However, considering that OSL dates are quite consistently in the late Pleistocene, along with the lack of organic matter in this part of the section which is consistent with a dryer latest Pleistocene climate, we argue that the best estimated age for event $\mathrm{E} 1$ is more likely close to $11 \mathrm{ka}$.

The penultimate event, designated as E2 in Figure 6, ruptured the eastern (lower) fault strand up through the stratified sediment of $\mathrm{Qa}_{6}$, and is overlain by more sediment of $\mathrm{Qa}_{6 \mathrm{a}}$. The fault rolls over to the palaeosurface, much like the upper, western strand, and is clearly truncated by unfaulted alluvium of $\mathrm{Qa}_{6 \mathrm{a}}$. We dated two samples from unit $\mathrm{Qa}_{6 \mathrm{a}}$ and one sample from unit $\mathrm{Qa}_{6 \mathrm{~b}}$, which place constraints on the timing of this event. All three dates are slightly discordant in that the oldest is apparently above the youngest, but considering the uncertainties, they all overlap and are about the same age (Table 2). As they are maximum ages, event E2 is younger than $c .14 \mathrm{ka}$ but older than the capping unit $\mathrm{Qa}_{5 \mathrm{a}}$ at $c .11 \mathrm{ka}$. We therefore infer the age of E2 as being 11-14 ka.

A probable third event, designated as E3 on Figure 6, is indicated by the presence of a wedge of colluvial (unit $\mathrm{Qa}_{6 c}$ ) that thickens towards and is terminated by the lower fault. The observation that this deposit thickens into the fault is diagnostic of fault-generated colluvial wedges. Unfortunately, this inference is based on only a stratigraphic observation and there are no separate faults that ruptured in this event, although subsequent activity (E2 and E1) may have obscured the structural evidence for this event. Nevertheless, with a lesser degree of certainty, we infer that a surface-rupturing event may have produced this colluvial wedge.

We dated two OSL samples from the wedge sediments, both of which yielded dates around $16 \mathrm{ka}$ (Table 2). However, the sediments from unit $\mathrm{Qa}_{6 \mathrm{~d}}$ directly below the wedge yielded an age of $14.5 \pm 2.4 \mathrm{ka}$, which appears slightly younger but overlaps with the dates from $\mathrm{Qa}_{6 \mathrm{~d}}$. Taken together, and assuming that the wedge represents the occurrence of a real event, E3 occurred at $c$. 14.0$14.5 \mathrm{ka}$, assuming no significant inheritance in the OSL signal from the deepest sample and minor inheritance from the two samples from the wedge.

In summary, we observed evidence for two and probably three surface ruptures on the Vilariça fault segment at Vale Meão between $c .14 .5$ and $4.8 \mathrm{ka}$, with a high likelihood that all three occurred between 14.5 and $11 \mathrm{ka}$, or soon thereafter. Although this yields an average late Quaternary return period of $c .5 \mathrm{ka}$ if all three events are real, and closer to $6-7 \mathrm{ka}$ if only E1 and E2 are real, the events appear clustered with interevent times during the cluster of less than $2 \mathrm{ka}$. It is clear that there is an open interval at 4.8 to $11 \mathrm{ka}$, but intervals between clusters in intracontinental regions are poorly known and could range to many tens of thousand of years or longer.

\section{Vilariça site}

The Vilariça site lies on the floodplain of the Vilariça River c. $2 \mathrm{~km}$ north of its confluence with the Sabor River (Fig. 1). The site was chosen because there is an apparent scarp, with bedrock cropping out to the east. The escarpment approximately follows the trace of the fault, although the active trace of the fault is buried by very young alluvium and the base of the scarp represents the area where the young sediments are ponded against rock.

Four trenches were initially opened at the Vilariça site to explore the location of the fault and the timing of past slip events (Fig. 7). Trench VR-1, which is the longest of all of the exposures and was excavated as the locator trench, exposed the main fault east of the sequence of Holocene alluvial deposits $(\mathrm{Qal})$ in which we had hoped to capture the faulting history, so we do not include the log. The main fault juxtaposed Cambrian chloritic phyllite of the Pinhao Formation against very old Quaternary alluvial deposits (Qoa) at the base of the trench. We also observed several minor 


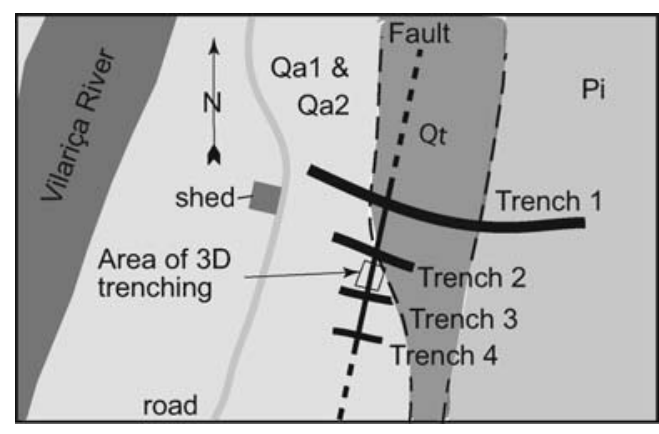

Fig. 7. Schematic map of the Vilariça trench site showing the spatial relations between trenches. The 3D trenching was conducted between trenches 2 and 3 .

secondary shears in the phyllite itself, just east of the main fault. The age of the Qoa is inferred to be middle Quaternary or older based on its very red (10R 7/8d) colour and degree of cementation, but could well pre-date the Quaternary altogether. The Qal deposits in the western part of the trench were reasonably well-stratified and contained abundant detrital charcoal, two pieces of which were dated from trench VR-3 that yielded late Holocene ages (after $c$. AD 1400; Table 1).

Stratigraphy was lacking within the fault zone, which made the assessment of the timing of past events impossible. We therefore decided to excavate additional trenches to the south where we expected the younger alluvium to cross the fault. Towards that end, trench VR-2 was excavated parallel to VR-1, but c. $10 \mathrm{~m}$ south followed by VR-3 and VR-4 (Fig. 7). Each successive trench exposed the fault in deeper and thicker fluvial deposits such that the fault was at or below the level of groundwater in VR-4. The margin of a channel deposit (Qa2) in trench VR-2 (Fig. 8, south face), however, was $c .2 \mathrm{~m}$ west of the fault, whereas the correlative deposit was in fault contact on the east side in both the northern and southern trench face exposures. In trench VR-3, the same channel deposit was in fault contact on both sides of the fault (Fig. 9). This implied that the channel's western margin intersected the fault in the volume of earth between the two trenches. Similarly, the equivalent eastern margin must intersect the fault between trenches VR-1 and VR-2. These set up the 3D exercise to resolve displacement on the channel margin, as none of the critical piercing points were removed in the initial trenching.

\section{Age of deposits}

We collected and dated four samples for OSL dating from the Vilariça trenches with the intent to test the ages of deposits that could potentially yield information on timing and displacement. We also used radiocarbon dating of detrital charcoal to date the young unfaulted channel alluvium (Qa1) that buries the older, faulted deposits.

The radiocarbon dating showed that the Qa1 alluvium is very young, on the order of a few hundred years (Table 1), and was not useful in constraining the timing of the most recent event. The Qa2 channel was sampled in two exposures for OSL dating, and both the channel alluvium and the overlying overbank (fine sand) deposits yielded results. We analysed up to 28 aliquots per sample and found that there was significant spread among the individual aliquot ages, which suggests a strong inherited signal. We also re-ran sample splits for dose rate and got generally similar

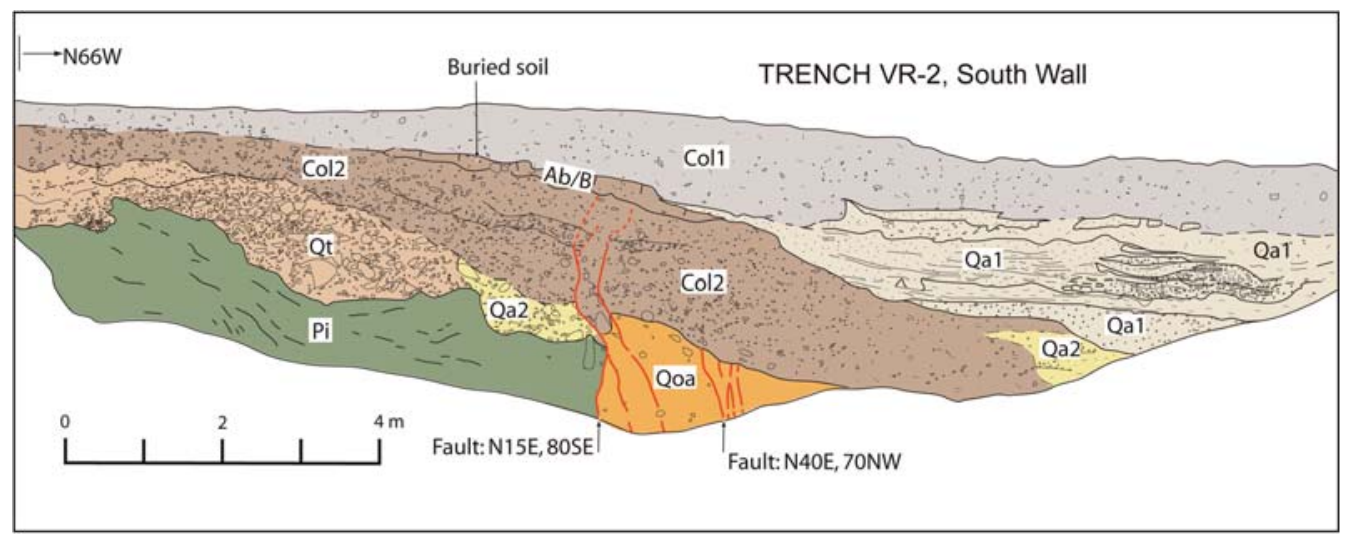

Fig. 8. Log of the Vilariça VR-2 trench, south wall. The Qa2 alluvium, which was used to resolve displacement, interfingers with the colluvium of $\mathrm{Col} 2$, part of which is derived from the gravelly deposits of an older terrace deposit (Qt). The primary discriminator was whether the gravel is matrix-supported (colluvial) or grain-supported (fluvial). 


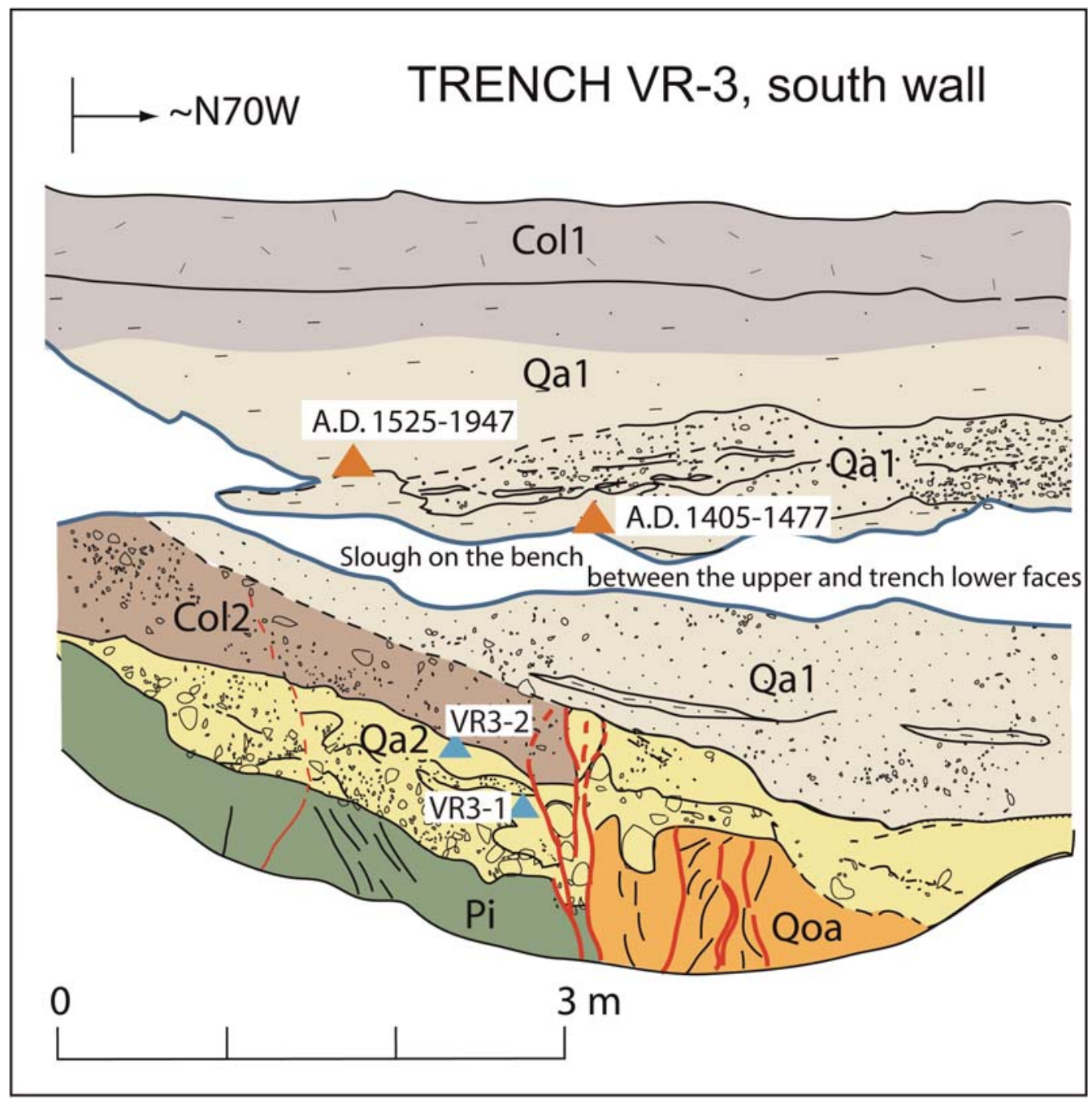

Fig. 9. Log of Vilariça trench VR-3, south wall. Note that the Qa2 alluvium is in complete fault contact, indicating that the channel margin lies between trenches VR-2 and VR-3. The eastern margin was exposed both in VR-2 and VR-3 and is the edge of the Qa2 deposits on the left side of the log. Also note the position of two of the OSL samples used to constrain the age of the Qa2 alluvium.

results (within $c .0 .5 \mathrm{mGy}$ ). For the age calculations, we present results from both dose rates, as well as their mean (Table 2).

For the channel deposits, sample VR3/3 from slice 4 of the 3D trenches yielded an average age of $30.4 \pm 2.4 \mathrm{ka}$. However, the lowest $20 \%$ of aliquots averaged only $23.1 \pm 1.3 \mathrm{ka}$, again indicating a strong inheritance component. Sample VR3-1 yielded an apparent minimum age of $c$. $24 \mathrm{ka}$, as the grains are OSL-saturated. However, considering the likely effect of partial bleach (inheritance) on this sample too, this may well be a maximum age. In any case, although it generally corroborates the results from VR3/3, the fact that the OSL signal is saturated makes this not very useful. Based on these results, and heavily weighting the results from VR3/3, we infer the maximum age of the channel to be $c .23 \mathrm{ka}$.

Sample VR3-2 was collected from a fine-grained sand unit that directly overlies the gravel component of the channel (Fig. 9). There was no evidence of weathering or surface exposure between these units, and they fill the same channel form, so we expected the results to be similar. The OSL analyses yielded an age of $18.2 \pm 1.6 \mathrm{ka}$, several thousand years younger than the underlying coarse channel 
alluvium. Taken together, along with the lack of weathering or erosion between units, we suspect that the $c .18 \mathrm{ka}$ age is closer to the true age of the channel complex. If correct, then the channel is similar in age to the base of the alluvium at the Vale Meão palaeoseismic site. In any case, it appears that the channel should record slip from all of the two or three events exposed at Vale Meão, and possibly additional ones if the channel is as old as c. $23 \mathrm{ka}$.

The fourth sample for OSL dating (VR2-4) was collected from the north wall of trench VR-2 from terrace deposits logged as Qt in Figure 8. This deposit was exposed in both trenches VR-1 and VR-2 on the east side of the fault. This deposit is older than the Qa2 alluvium, as the latter deposits are incised into the Qt deposits, so the age of this unit provides additional age control on the maximum age of the Q22 alluvium that we used to resolve slip. Furthermore, it may provide a source of inheritance if a significant amount of the Qt deposits were incorporated into the Qa2 alluvium. Sample VR2-4 yielded an age of $38.6 \pm 2.7 \mathrm{ka}$, consistent with the stratigraphy and younger age of Qa2, and confirms the late Quaternary age of the alluvial sequence. The margin of the Qt deposits must cross the fault somewhere north of trench VR-1 and will potentially provide a longer period over which to assess the slip rate in future studies.

\section{Resolution of slip}

We explored the three-dimensional distribution of the Qa2 alluvium where it crosses the fault zone, with special attention to using the channel margin as a piercing point. The channel margin, as seen in the south wall of trench VR-2, has two elements that looked useful: the tread/riser intersection; and the top edge of the channel gravel itself. We mapped both of these features in 3D across the fault. (Note that only the top edge of the channel is evident on Fig. 8, as we deepened and lengthened trench VR-2 prior to starting the 3D exercise.)

The Qa2 alluvium was generally c. $2.5-3.0 \mathrm{~m}$ below the modern ground surface, and 3D trenching at these depths can be hazardous without adequate trench bracing (shoring). Instead, we removed the upper $1.5-2 \mathrm{~m}$ of sediment from the site over the entire area between trenches VR-2 and VR-3, making a flat surface from which to work, and keeping the depths of the trenches to $c .1 \mathrm{~m}$ (Fig. 10). We then opened two trenches parallel to the fault, one on each side and located 1-2 m from the fault. This left an intact block of soil that contains the fault, the Qa2 alluvium near the fault, and the expected western piercing point (Figs 11 and 12a). We set a grid system on the surface of the block by establishing an orthogonal system of

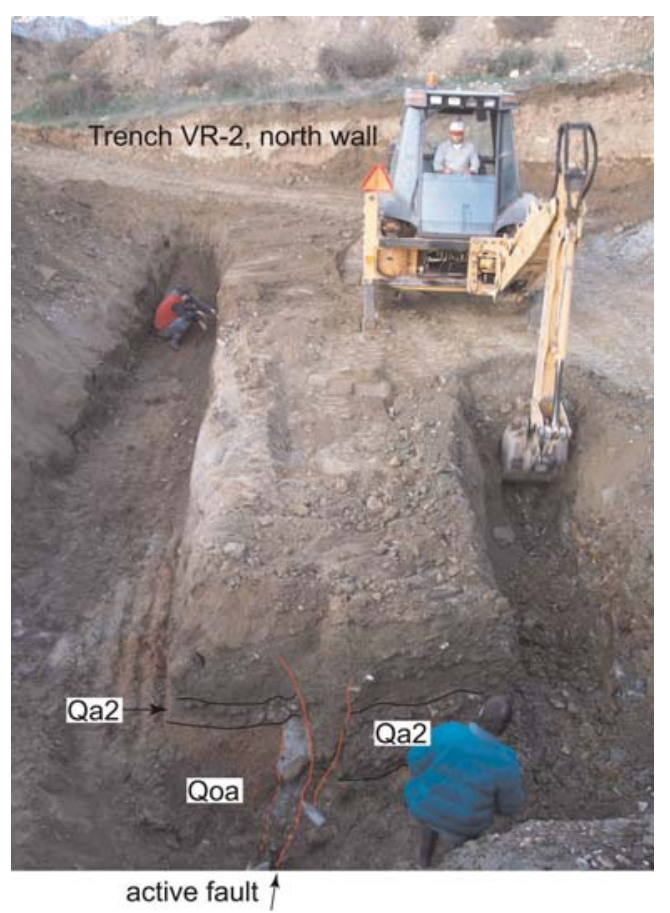

Fig. 10. Set-up for the 3D trenching, looking from trench VR-3 towards VR-2. Note that the fault zone is highly localized, which is ideal for resolution of displacement. The units are described in the text.

large nails connected by string: this new grid was tied to the original grid reference frame in trenches VR-2 and VR-3. We also continued the grid into the fault-parallel trenches so that all significant features could be located to within a few centimetres. Although surveying would have been preferable for accuracy of locations, this method allowed us to plot everything in the field as each cut was made, and a few centimetres of imprecision is negligible when considering offsets at the metre scale. This also allowed for rapid decisions on the next cuts.

We then began to trace the western channel margin into the fault by cutting successive slices across the fault in 'the block' (Figs 11 and 12). Each exposure was photographed and logged in the field, and the location of each cut determined with the grid reference system (Fig. 12).

After resolving the location of the piercing point west of the fault, we turned to the north face of trench VR-2, where both the riser (R) and channel margin (C) piercing points were preserved (Fig. 13a). We cut the trench face back $c .0 .5 \mathrm{~m}$, and in so doing removed the piercing point, so we know its location to $\pm 25 \mathrm{~cm}$ (half the cut distance) (Fig. 11). 


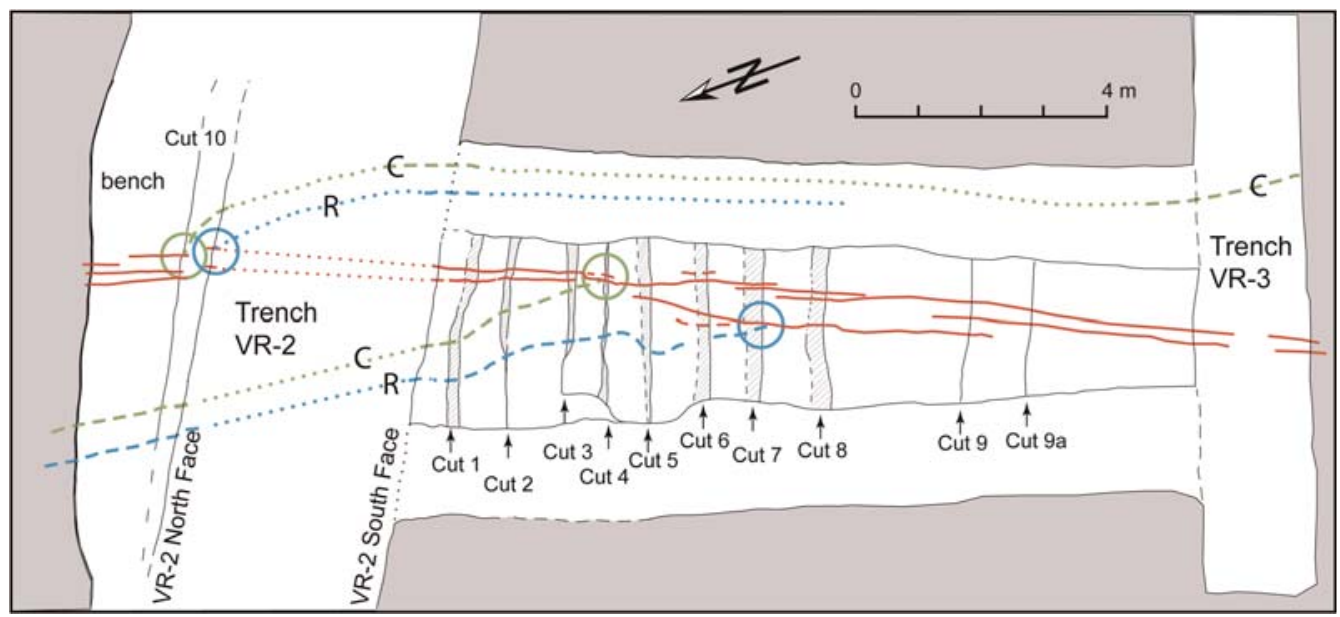

Fig. 11. Detailed map of the area between trenches VR-2 and VR-3 showing the locations of each trench and cut, the fault strands, the location of the channel edge and tread/riser contact, and the piercing points at the fault.

Figure 11 shows the location of both piercing lines as they were traced from exposure to exposure. Figure 14 is a simplification of the offset piercing lines and shows that the riser is laterally offset c. $8.9 \mathrm{~m}$ whereas the channel margin is displaced c. $6.5 \mathrm{~m}$. As the exposures were closely spaced, we know the locations of the piercing point/fault intersection to within $c .25 \mathrm{~cm}$ for each side of the fault, so we assign an uncertainty of $c .0 .5 \mathrm{~m}$ for these displacements. Thus, we assign displacement values of $6.5 \pm 0.5 \mathrm{~m}$ for the channel edge and $8.9 \pm 0.5 \mathrm{~m}$ for the channel bed and riser.

It is interesting that the channel tread/riser and gravel lag are apparently displaced more than the top channel edge. Our preferred interpretation is that the channel was active during a large displacement event, so the difference represents slip in that event. If true, this suggests a displacement of c. $2.4 \mathrm{~m}$ for an event that is constrained to between $c .18$ and $23 \mathrm{ka}$ if the OSL ages read true, or younger than $18 \mathrm{ka}$ if the OSL ages are maximum ages and the channel alluvium is all c. $18 \mathrm{ka}$ or less.

\section{Other constraints on slip per event}

Although we have resolved slip for the past $c$. 18$23 \mathrm{ka}$ at the Vilariça site, we also make inferences from the deflection of a small channel at Vale Meão winery that may represent slip after incision of the Douro River below the level of the $c .16 \mathrm{ka}$ fill event.

The fault is exposed in the river riser on the southwestern margin of Vale Meão winery where the fault cuts into the Douro River gorge. In the vicinity of the small channel at the base of the slope, colluvium covers the fault but bedrock outcrops upslope allow for placement of the fault to within $\pm 3 \mathrm{~m}$ close to the channel. At this location, the small rill is deflected exactly where the fault projects through the rill, suggesting that the deflection is the result of fault slip (Fig. 15). The small rill was surveyed with a total station, and the map generated from that survey is presented as Figure 15. In the field, we estimated $c .2 \mathrm{~m}$ of deflection in the near-field, and that estimate is refined to $c$. 2.0 $2.5 \mathrm{~m}$, as shown in Figure 15. However, the far-field deflection of the rill is $c .6 .1 \mathrm{~m}$, as measured along the strike of the fault. The smaller deflection reflects the fairly abrupt jog in the channel at the fault, whereas the larger deflection appears to reflect the total offset of the drainage. Taken together, we interpret the $6.1 \mathrm{~m}$ to represent slip in the past two or three events, with the most recent event 'freshening' the deflection in the vicinity of the fault by $c .2-$ $2.5 \mathrm{~m}$. The other possibility is that the $6.1 \mathrm{~m}$ deflection is the result of only one event and that this reflects slip in the most recent event with substantial off-fault bending, as has been documented in recent earthquakes (Rockwell et al. 2002; Treiman et al. 2002). However, because the near-field deflection appears to be superposed on the farther-field deflection, and because there is no thick cover of alluvium as is typical in areas of off-fault bending, we prefer an interpretation where the overall $6.1 \mathrm{~m}$ deflection has resulted from at least two and possibly three events. Furthermore, because of the uncertainty in interpretation of the deflected channel, we use the range of possible values to infer slip per event $(2-3 \mathrm{~m})$, assuming that the far-field deflection has resulted from at least two but not more than three events. 


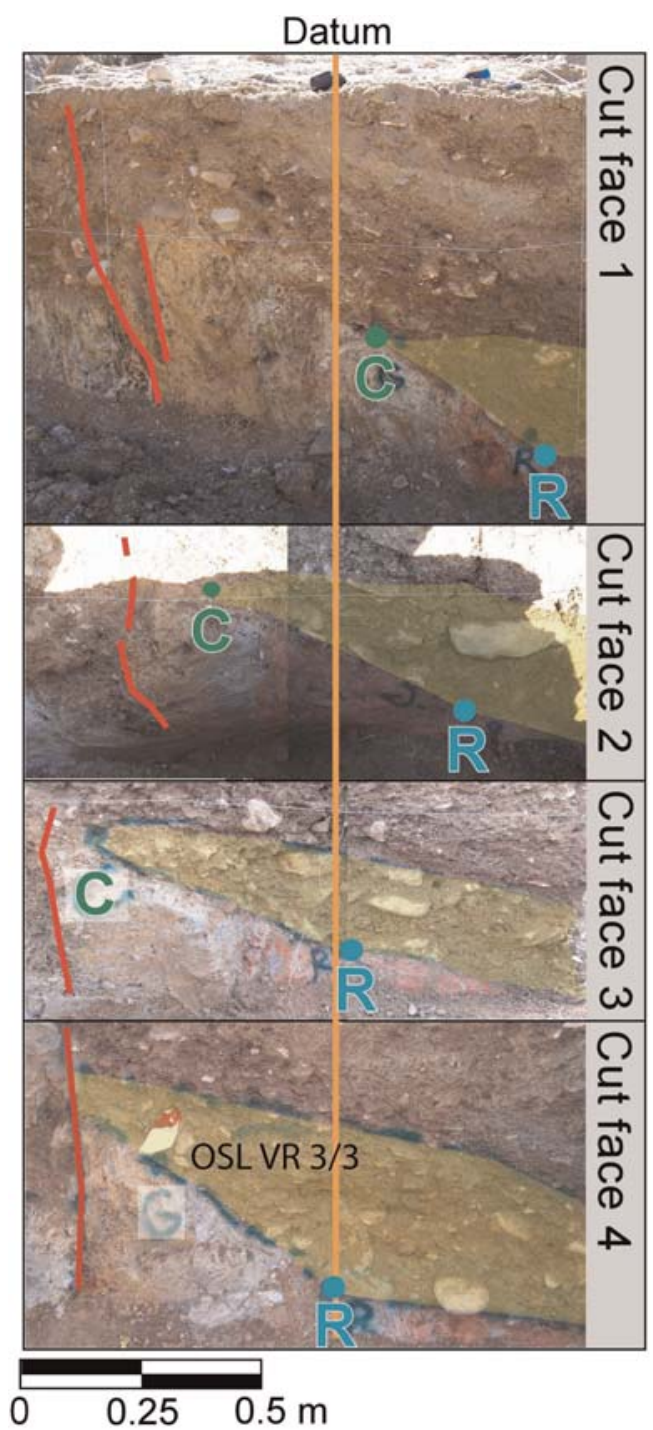

Fig. 12. First four cuts or slices into the block used to trace the location of the channel edge $(\mathrm{C})$ and the tread/ riser $(\mathrm{R})$ into the fault. Cuts 5 to 7 determined the location of $\mathrm{R}$ at the fault (not shown). Note the location (flagging) of OSL sample VR $3 / 3$.

The age of the rill must be younger than the c. $16 \mathrm{ka}$ fill event represented by the prominent terrace along the Douro River, as the rill is topographically below this level. Consequently, it can only represent slip that has occurred after $16 \mathrm{ka}$, or only the past two to three events as determined at the Vale Meão trench site. The $6.1 \mathrm{~m}$ of deflection is very similar to the $c .6 .5 \mathrm{~m}$ of offset of the channel margin at the Vilarica site which has occurred in a similar timeframe of $<18 \mathrm{ka}$. Taken together,
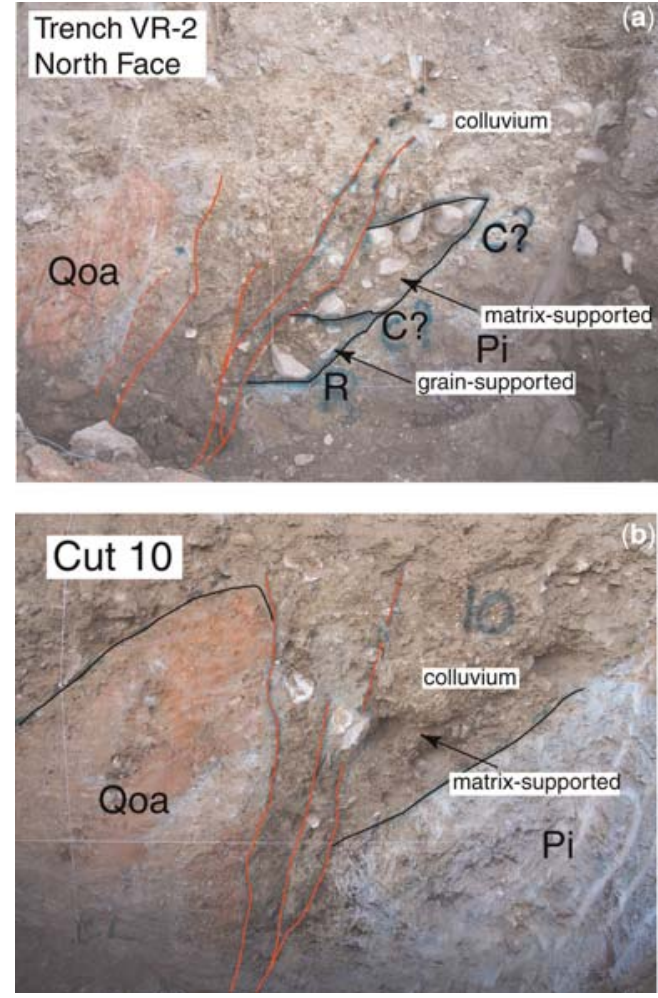

Fig. 13. Remnant of both piercing points exposed in the north face of trench VR-2. Note that we are uncertain whether the actual channel margin is represented by the upper or lower edge of the coarse, bouldery deposits, as the upper portion is partially matrix-supported and could be interpreted as colluvium. In either case, both contacts intercepted the fault between the VR-2 face and cut 10, as shown in (b), so their location at the fault is known to within $\pm 25 \mathrm{~cm}$.

these observations make a strong argument for relatively large displacements on the Vilariça fault in the late Quaternary, with evidence preserved both at the surface and in the subsurface.

\section{Estimation of slip rate}

We have determined that two and probably three surface ruptures have occurred on the Vilariça fault in the past $14.5 \mathrm{ka}$ at the Vale Meão site. We have also inferred $c .6 \mathrm{~m}$ of slip in the same timeframe from deflection of a small rill at Vale Meão. Taken together, these observations argue for 2-3 $\mathrm{m}$ of displacement every 5-7 ka, suggesting a rate of $c .0 .3-0.6 \mathrm{~mm} / \mathrm{a}(2-3 \mathrm{~m}$ events with a recurrence of $7 \mathrm{ka}$ is $c .0 .29-0.43 \mathrm{~mm} / \mathrm{a} ; 2-3 \mathrm{~m}$ events every $4.5 \mathrm{ka}$ is $c .0 .44-0.66 \mathrm{~mm} / \mathrm{a} ; 6.1 \mathrm{~m}$ in $<16 \mathrm{ka}$ is a minimum rate of $0.38 \mathrm{~mm} / \mathrm{a}$ ). 


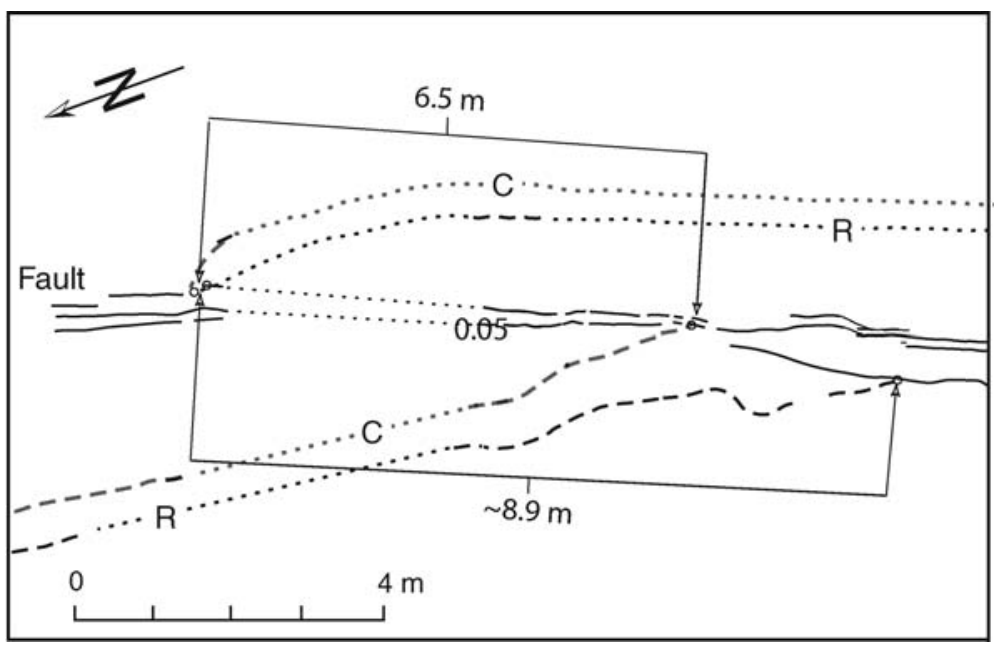

Fig. 14. Simplification of Figure 11 showing the estimates of displacement for the channel margin $(C)$ and riser $(R)$.

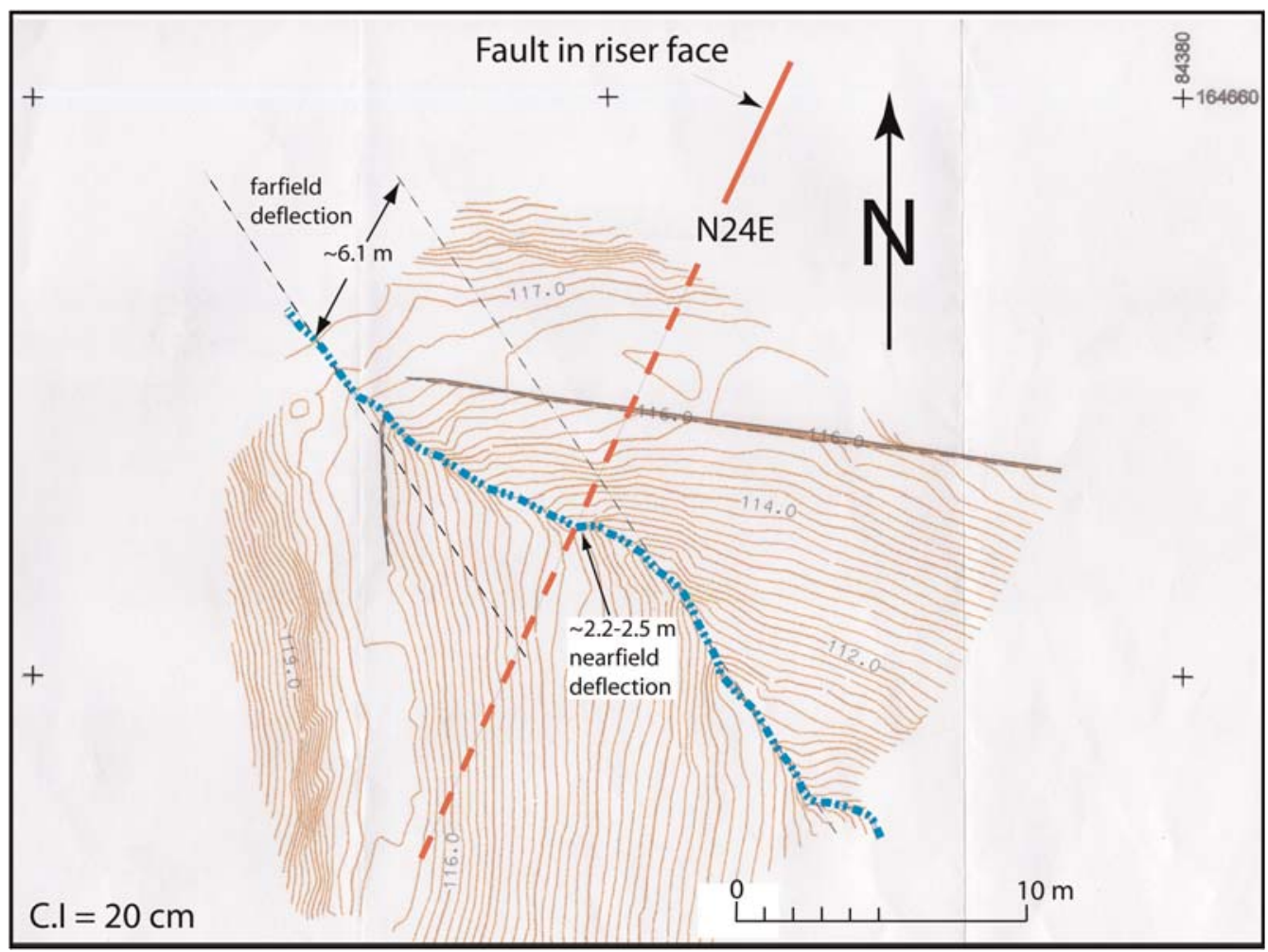

Fig. 15. Surveyed map of a small deflected channel on the SW edge of the Vale Meão winery. Contour interval is $20 \mathrm{~cm}$. The field estimate of deflection was about $2 \mathrm{~m}$, similar to the surveyed estimate of near-field deflection. The far-field deflection probably represents slip from multiple events. 
Similarly at the Vilariça site, we resolved c. $6.5 \mathrm{~m}$ of displacement in less than the past $18 \mathrm{ka}$ $(>0.35 \mathrm{~mm} / \mathrm{a})$ and $c .8 .9 \mathrm{~m}$ in less than $23 \mathrm{ka}$ $(>0.38 \mathrm{~mm} / \mathrm{a})$ with the likelihood that both offsets are $<18 \mathrm{ka} \quad(0.5 \mathrm{~mm} / \mathrm{a})$. The absolute maximum age of the $8.9 \mathrm{~m}$ offset is the age of the Qt deposits (38.6 $\pm 2.7 \mathrm{ka})$ into which the Qa2 alluvium is incised, yielding an absolute minimum longer-term rate of $0.23 \mathrm{~mm} / \mathrm{a}$.

All of these observations at both Vale Meão and Vilariça are consistent with each other and make a robust set of data that argues for a preferred slip rate in the range of 0.3 to $0.5 \mathrm{~mm} / \mathrm{a}$ for the late Quaternary. The uncertainty is larger than this range suggests because we do not know the variability in long-term seismic production rate. Our data suggest that the events were clustered, and that by sampling the cluster in our estimation of rate, we may have overestimated the rate. Nevertheless, this rate agrees favourably with the longterm Quaternary rate suggested by Cabral (1989) based on his interpretation of deflection of the Douro River.

\section{Estimate of earthquake magnitude}

The size of an earthquake is directly proportional to the average amount of slip and the surface area of rupture. Wells \& Coppersmith (1994) compiled historical surface ruptures and regressed a number of properties (average and maximum slip, rupture length) against magnitude. Using the equations for strike-slip faults $(M=7.04+0.89 \log (A D)$ and $M=6.81+0.78 \log (M D)$, where $A D=$ average displacement and $M D=$ maximum displacement), and using the displacement values of $2.0-2.5 \mathrm{~m}$ for average displacement in individual earthquakes, we estimate the magnitude of these events is on the order of $\mathrm{Mw}$ 7.3. If these are maximum slip values, then the magnitude range is closer to Mw 7.1. In either case, it is likely that the palaeoevents that we identified on the Vilariça fault represent slip in relatively large earthquakes in the $\mathrm{M} 7+$ range.

As an independent check on our magnitude estimates, we assessed the Vilariça fault segment in terms of its segmentation or continuity. The fault is virtually straight for a distance of about $75 \mathrm{~km}$ between Longrovia northward to the vicinity of Macedo de Cavaleiros (Fig. 1), where the fault makes a complex restraining bend, several kilometres wide. At Longrovia, the fault makes a relatively minor 2-km-wide releasing step. A $75 \mathrm{~km}$ length is consistent with earthquakes at the upper end of our magnitude range and supports the idea that this fault is capable of producing relatively large events.

\section{Conclusions}

We have demonstrated that the Vilariça fault in northeastern Portugal has sustained multiple surface ruptures in the late Quaternary (over last $c$. 30000 years), each likely producing multiple metres of slip (Fig. 16). The most recent surface slip occurred between c. 4.8 and $11 \mathrm{ka}$, but is most likely close to the older end of this range, indicating that there is an open interval of c. 5-11 ka. At least two and probably three large slip events occurred on the fault in the past $14.5 \mathrm{ka}$, suggesting an average return period in the range of 5 to $7 \mathrm{ka}$ but with the high likelihood that the events were clustered in time. Clustering is common in intracontinental settings (Crone \& Wheeler 2000) and suggests that the Vilariça segment of the Manteigas-Bragança fault is behaving as a typical intracontinental fault.

In the same timeframe as the occurrence of the two or three events, we resolved that at least $6.5 \mathrm{~m}$, and possibly as much as $9 \mathrm{~m}$, of displacement accompanied these events (Fig. 16), arguing that these earthquakes were in the magnitude range of M7+. Combining information on displacement and the age of the alluvial units, we suggest that the slip rate is on the order of $c .0 .4 \mathrm{~mm} / \mathrm{a}$ and is not likely more than $0.5 \mathrm{~mm} / \mathrm{a}$. Provided that the open interval is at least $5 \mathrm{ka}$, there has likely been at least $2 \mathrm{~m}$ of accumulated elastic strain on the Vilariça fault, similar to our minimum estimate of slip in the past events. If the Vilariça fault behaves in a clustered mode, however, it could still be several thousand years (or longer) before the next cluster begins. We could also have overestimated the slip rate by sampling a cluster of events if the intercluster period ranges into tens of thousands of years. It will be important to try to establish both a

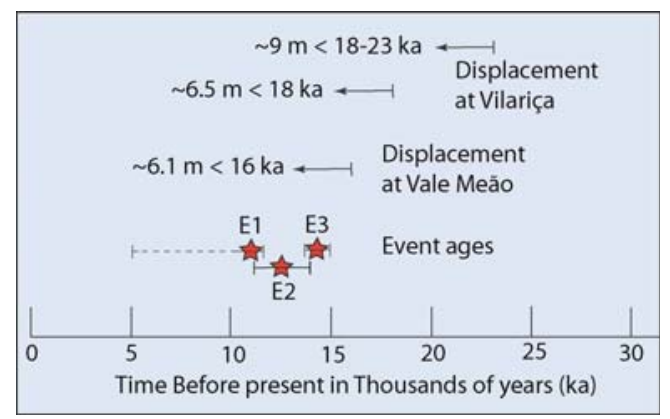

Fig. 16. Summary of palaeoseismic data from the Vilariça segment of the Manteigas-Bragança fault zone. The two or three documented surface ruptures apparently cluster in time between $c .14 .5$ and $11 \mathrm{ka}$, and produced 6.1-6.5 m of left-lateral slip. The slightly older Qa2 terrace tread at the Vilariça site is offset $c .9 \mathrm{~m}$ and may represent the occurrence of an additional event, or it may be a better measure of displacement in all three events. 
better date for the most recent Vilariça event, as well as to extend the record back to include events associated with the previous cluster. Only then can we increase the reliability of any forecast that uses time-based conditional probabilities.

Finally, our studies demonstrate that there are potential seismic sources in western Iberia that are not associated with the 1755 Lisbon earthquake or the Tagus Valley and, although rare, large events on the Vilariça fault could be quite destructive for the region. As there are other major faults with evidence of Quaternary activity in Portugal (Cabral \& Ribeiro 1988), these observations collectively argue for continued Alpine shortening in western Iberia, albeit at low rates.

We thank Electricidade de Portugal (EDP) for the opportunity to work on this project and permission to publish the results. We also thank the many landowners who granted access and allowed the subsurface investigations. We especially appreciate the cooperation of Mr Francisco Olazabal of Quinta de Vale Meão, who not only allowed access to his land but graciously introduced us to his secrets of making and tasting among the best wine in Portugal. We thank Tim Debey at the USGS Nuclear Reactor Facility in Denver for making the NAA measurements for the OSL dating. Finally, we thank João Cabral and Matthieu Ferry for their excellent reviews and meticulous attention to detail.

\section{References}

Adamiec, G. \& Aitken, M. 1998. Dose-rate conversion factors: update. Ancient TL, 16, 37-50.

AitKen, M. J. 1998. An Introduction to Optical Dating. Oxford University Press, Oxford.

Arthaud, F. \& Matte, P. 1975. Les decrochements tardi-Hercyniens du sud-ouest de L'Europe. Geometrie et essai de reconstitution des conditions de la deformation. Tectonophysics, 25, 139-171.

CABRAL, J. 1989. An example of intraplate neotectonic activity, Vilariça basin, Northeast Portugal, Tectonics, 8, 285-303.

Cabral, J. \& Ribeiro, A. 1988. Carta Neotectónica de Portugal Continental, escala 1/1000 000. Serviços Geológicos de Portugal, Lisboa.

Crone, A. J. \& WheEler, R. L. 2000. Data for Quaternary faults, liquefaction features, and possible tectonic features in the central and eastern United States, east of the Rocky Mountain front. US Geological Survey Open-File Report, 00-0260.

Crone, A. J., Machette, M. N., Bradley, L.-A. \& MAHAN, S. A. 1997. Late Quaternary surface faulting on the Cheraw Fault, Southeastern Colorado. Geologic Investigations Map, USGS Map I-2591.

FonsecA, J. F. B. D. \& LonG, R. E. 1991. Seismotectonics of SW Iberia: A distributed plate margin? In: Mostena, T. \& Udias, A. (eds) Instituto Geografico National, Madrid, Memoria 8.

FuCHS, M. \& LANG, A. 2008. Luminescence dating of hillslope deposits - a review. Geomorphology (in press).
Grimaud, S., Boillot, G., Collette, B. J., Mauffret, A., Miles, P. R. \& Roberts, D. B. 1982. Western extension of the Iberian-European Plate boundary during the early Cenozoic (Pyrenean) convergence: A new model. Marine Geology, 45, 63-77.

KenT, G. M., BABCOCK, J. M. ET AL. 2005. 60 k.y. record of extension across the western boundary of the Basin and Range province: Estimate of slip rates from offset shoreline terraces and a catastrophic slide beneath Lake Tahoe. Geology, 33, 365-368.

LeE, J., Spencer, J. Q. \& OWEN, L. A. 2001. Holocene slip rates along the Owens Valley fault, California: Implications for the recent evolution of the Eastern California Shear Zone. Geology, 29, 819-822.

Machette, M. N., Personius, S. F. \& Nelson, A. R. 1992. The Wasatch Fault Zone, USA. Annales Tectonicae, 6, 5-39.

Marques, F. O., Mateus, A. \& Tassinari, C. 2002. The Late-Variscan fault network in central-northern Portugal (NW Iberia): A re-evaluation. Tectonophysics, 359, 255-270.

MEJDAHL, V. 1979. Thermoluminescence dating: beta attenuation in quartz grains. Archaeometry, 21, 61-73.

Murray, A. S. \& Wintle, A. G. 2000. Luminescence dating of quartz using an improved single-aliquot regenerative-dose protocol. Radiation Measurements, 32, 57-73.

Owen, L. A., Cunningham, W. D., Richards, B., Rhodes, E. J., Windley, B. F., DornjamuaA, D. \& BadAmgaraV, J. 1999. Timing of formation of forebergs in the northeastern Gobi Altai, Mongolia: Implications for estimating mountain uplift rates and earthquake recurrence intervals. Journal of the Geological Society, 156(3), 457-464 (Erratum: Journal of the Geological Society, 156, Contents xii).

Prescott, J. R. \& Hutton, J. T. 1994. Cosmic ray contributions to dose rates for luminescence and ESR dating. Large depths and long-term time variations. Radiation Measurements, 23, 497-500.

Ribeiro, A. 1974. Contribution a l'etude de Trás-osMontes Oriental. Memorias Servicos Geologicas de Portugal, 24.

Ribeiro, A. 1981. A geotraverse through the Variscan fold belt in Portugal. In: ZWART, H. J. \& DornsiePEN, U. F. (eds) The Variscan Orogen in Europe. Geologie en Mijnbouw, 60, 41-44.

RiBEIRO, A. ET AL. 1979. Introduction a la geologie générale du Portugal. Serviços Geológicos de Portugal, Lisbon.

Ribeiro, A., Kullberg, M. C., Kullberg, J. C., Manuppella, G. \& Phipps, S. 1990. A review of Alpine tectonics in Portugal: Foreland detachment in basement and cover rocks. Tectonophysics, 184, 357-366.

Rockwell, T. K., Johnson, D. L., Keller, E. A. \& Dembroff, G. R. 1985. A late Pleistocene-Holocene soil chronosequence in the central Ventura Basin, Southern California, U.S.A. In: RICHARDS, K., ARnetT, R. \& Ellis, S. (eds) Geomorphology and Soils. George Allen and Unwin, London, 309-327.

Rockwell, T. K., Lindvall, S., Herzberg, M., Murbach, D., Dawson, T. \& Berger, G. 2000. 
Paleoseismology of the Johnson Valley, Kickapoo and Homestead Valley faults of the Eastern California Shear Zone. Bulletin of the Seismological Society of America, 90, 1200-1236.

Rockwell, T. K., Lindvall, S., Dawson, T., LANGRIDGE, R. \& LETTIS, W. 2002. Lateral offsets on surveyed cultural features resulting from the 1999 Izmit and Duzce earthquakes, Turkey. Bulletin of the Seismological Society of America, 92, 79-94.

Sobrino, C. M., Rego, P. R. \& Gomez-Orellana, L. 2007. Late Wurm and early Holocene in the mountains of northwest Iberia: Biostratigraphy, chronology and tree colonization. Vegetation History and Archaeobotany, 16, 223-240.

Treiman, J. A., Kendrick, K. A., Bryant, W. A., RockWell, T. K. \& McGill, S. F. 2002. Primary surface rupture associated with the Mw7.1 16 October, 1999 Hector Mine earthquake, San Bernardino County, California. Bulletin of the Seismological Society of America, 92, 1171-1191.
Vilanova, S. \& FonsecA, J. F. B. D. 2007. Probabilistic seismic-hazard assessment for Portugal. Bulletin of the Seismological Society of America, 97, 1702-1717.

Washburn, Z., Arrowsmith, J. R., Forman, S. L., Cowgill, E., Wang, X., Zhang, Y. \& Chen, Z. 2001. Late Holocene earthquake history of the central Altyn Tagh fault, China. Geology, 29(11), 1051-1054.

Wells, D. L. \& Coppersmith, K. J. 1994. New emperical relationships among magnitude, rupture length, rupture width, rupture area, and surface displacement. Bulletin of the Seismological Society of America, 84, 974-1002.

Wesnousky, S. G., Barron, A. D., Briggs, R. W., Caskey, S. J., Kumar, S. \& Owen, L. 2005. Paleoseismic transect across the northern Great Basin. Journal of Geophysical Research, 110, B05408. DOI: 10.1029/2004JB003283.

ZIEGLER, P. 1982. Geological Atlas of Western and Central Europe. Shell Internationale Petroleum Maatschappij, B.V. 